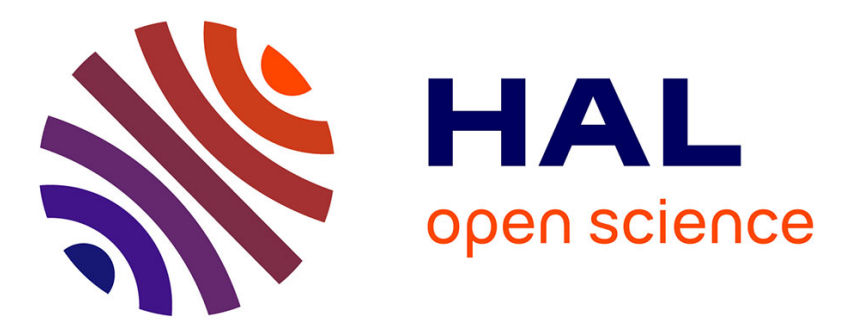

\title{
Climate change evolution of the hydrological balance of the Mediterranean, Black and Caspian Seas: impact of climate model resolution
}

\author{
Nellie Elguindi, Samuel Somot, Michel Déqué, Wolfgang Ludwig
}

\section{To cite this version:}

Nellie Elguindi, Samuel Somot, Michel Déqué, Wolfgang Ludwig. Climate change evolution of the hydrological balance of the Mediterranean, Black and Caspian Seas: impact of climate model resolution. Climate Dynamics, 2011, 36 (1-2), pp.205-228. 10.1007/s00382-009-0715-4 . hal-01000123

\section{HAL Id: hal-01000123 \\ https://hal.science/hal-01000123}

Submitted on 30 Nov 2021

HAL is a multi-disciplinary open access archive for the deposit and dissemination of scientific research documents, whether they are published or not. The documents may come from teaching and research institutions in France or abroad, or from public or private research centers.
L'archive ouverte pluridisciplinaire HAL, est destinée au dépôt et à la diffusion de documents scientifiques de niveau recherche, publiés ou non, émanant des établissements d'enseignement et de recherche français ou étrangers, des laboratoires publics ou privés.

\section{(c) (1) $\$$}

Distributed under a Creative Commons Attribution - NonCommerciall 4.0 International 


\title{
Climate change evolution of the hydrological balance of the Mediterranean, Black and Caspian Seas: impact of climate model resolution
}

\author{
Nellie Elguindi, S. Somot, M. Déqué, W. Ludwig
}

\begin{abstract}
In this study we have evaluated the ability of the CNRM-ARPEGE CLIMATE V4 general circulation model (GCM) to estimate the present-day hydrological budget components [precipitation minus evaporation over the sea $(P-E)$ and fresh water runoff $(R)]$ over the Mediterranean, Black and Caspian sea basins. Three simulations were performed which were exactly identical except for horizontal resolution, allowing for a unique opportunity to isolate and study the effects of resolution on simulating the hydrological components. Model calculated values of runoff and $P-E$ were compared to a variety of data sources and show that the model's performance improves significantly with increased resolution, especially in regions with mountainous terrain. Corresponding future climate simulations (following the IPCC A2 scenario) were also performed and indicate that while resolution does not seem to have a significant effect on the qualitative impacts of future climate change on the hydrologic balance, quantitatively the results vary significantly among the models. These results suggests that high resolution global models, or downscaling models such as RCMs, are necessary in order to assess the magnitude of future changes in the hydrological components of these basins.
\end{abstract}

\footnotetext{
N. Elguindi $(\square)$

Laboratoire D'Aerologie, CNRS, Toulouse, France

e-mail: nellie.elguindi@aero.obs-mip.fr

S. Somot · M. Déqué

Météo France, CNRM, Toulouse, France

W. Ludwig

CNRS, CEFREM, UMR 5110 CNRS,

University of Perpignan, Perpignan, France
}

Keywords Mediterranean - Caspian sea . Hydrologic balance $\cdot$ Climate change

\section{Introduction}

The Mediterranean, Black and Caspian Sea basins encompass vast and diverse regions extending over much of western and central Europe and into North Africa. The terrain across these regions ranges from desert to rugged mountains. An understanding of the potential future climate change impacts on the hydrological budget over these basins is important from several standpoints. First from a socio-economic standpoint, runoff from major river basins in these regions such as the Po, Rhone, Ebro, Volga, Danube and Nile provide essential water resources to millions of people. Sensitivity to current climate variability has already proven to be devastating to many of these regions. Over the last decades, the Mediterranean basin has experienced a general drying (Valero et al. 1996; Xoplaki et al. 2000; Boukthir and Barnier 2000; Alpert et al. 2002) probably linked with decadal variability of the NorthAtlantic Oscillation and a decrease in the strength of the Mediterranean cyclogenesis (Trigo et al. 2000). A positive phase of the NAO leads to less precipitation over the Mediterranean area in winter, the rainy season. The attribution of this trend to anthropogenic climate change has not been demonstrated up-to-now. This decrease in the mean precipitation amount is however accompanied by an increase in extreme precipitation (Alpert et al. 2002), showing the complexity of the Mediterranean water cycle. The Caspian Sea region is also very sensitive to climate variability. During the last century, large and rapid flucuations in the Caspian Sea level resulting from variations in the water budget components have had catastrophic 
consequences for the surrounding communities. During the late 1970s and 1980s, rapidly rising Sea levels wiped out many settlements along the shoreline and caused enormous amounts of pollution (Rodionov 1994).

Second, studies have shown that changes in the temperature and salinity of the Mediterranean Sea due to changes in the water budget components can have a significant direct impact on the Mediterranean thermohaline circulation (MTHC) as well as indirect impacts on the Atlantic ocean characteristics. This has been observed and modelled for paleo-events leading to anoxic situations for the Mediterranean deep waters and to the formation of sapropel layers during the weak MTHC phase (Bethoux 1993; Myers et al. 1998). Nowadays, this kind of thermohaline shifts due to change in the water budget of the Mediterranean Sea are also observed. For example, the impact of the damming of the Nile river on the Mediterranean water masses has been demonstrated (Rohling and Bryden 1992; Skliris and Lascaratos 2004). Moreover, the now well-known eastern Mediterranean transient (see Roether et al. 2007 for a recent review) has probably been partly driven by a drying in the eastern Mediterranean Sea in the early 1990s (Malanotte-Rizzoli et al. 1999), an increase in evaporation during the winters 1992 and 1993 (Josey 2003) and by the decrease in the Black Sea freshwater input towards the Aegean Sea (Zervakis et al. 2000). More recently, other water masses changes in the western Mediterranean Sea (Schroeder et al. 2008), at the Gibraltar Strait (Millot et al. 2006) and in the Mediterranean outflow waters in the Atlantic (Potter and Lozier 2004) also seem to be linked with changes in the water budget components of the Mediterranean Sea. Concerning regional climate change scenarios, the projected drying of the Mediterranean area would lead to a decrease of runoff and precipitation, an increase in evaporation (Giorgi 2006; Somot et al. 2006; Sanchez-Gomez et al. 2009a; Ludwig et al. 2009) and strong changes in MTHC and MOW characteristics (Thorpe and Bigg 2000; Somot et al. 2006). Third, changes in the hydrological budget of the Seas can potentially have large impacts on the marine ecosystems through changes in the hydrodynamic circulation patterns.

Given the significant impacts future climate change could have on the hydrological balance of the Mediterranean, Black and Caspian Sea basins, it is no surprise that much effort has already been devoted to improve our understanding of how projected climate change will impact the hydrological budget, mainly through the use of climate models (Mariotti et al. 2008; Somot et al. 2006; Elguindi and Giorgi 2007; Arpe and Leroy 2007; Sanchez-Gomez et al. 2009a). In addition, several large international projects have been devoted to further understand the present-day and potential future climate impacts on the hydrological balance of the Mediterranean and Caspian Sea basins (HYMEX, CIRCE, CASSEAS, CECILIA). While climate models are essential tools for evaluating potential climate change impacts, there is still a great deal of uncertainty in how well they can reproduce the hydrological budget over hydrological basins. One question which must be addressed is what is the minimum horizontal resolution necessary to accurately simulate the individual components of the hydrological budget. In some areas of the basins where orographic precipitation plays an important role in river runoff, coarse general circulation models (GCMs) may not be sufficient to accurately simulate the hydrological balance of the basin, and high resolution GCMs or downscaling, such as through the use of regional climate models, may be necessary. The main focus of this study is to determine how much of an effect horizontal resolution has on simulating the hydrological budget of the Mediterranean, Black and Caspian Seas. To this end, we analyze model output from three separate simulations performed using the ARPEGE-CLIMATE global model which are identical except for the horizontal resolution. Two simulations are run for each model, one for the present climate (1979-2002) and one for the future climate (2046-2070) following the IPCC SRES-A2 scenario. The high resolution model is run with a TL359 grid $\left(0.5^{\circ}\right.$ $\times 0.5^{\circ}$ latitude-longitude), the medium resolution model is run with a TL159 grid $\left(1.125^{\circ} \times 1.125^{\circ}\right.$ latitude-longitude), and the low resolution model is run with a TL63 grid $\left(2.8^{\circ} \times 2.8^{\circ}\right.$ latitude-longitude $)$. Hereafter, these models will be referred to as the HiRes, MedRes and LoRes models, respectively. Because the only difference between the three models is horizontal resolution, this sensitivity experiment is very clean and offers a unique opportunity to isolate and study the effects of resolution on simulating the hydrological components of the Mediterranean, Black and Caspian Sea basins.

In this study, we attempt to address the following three questions:

(1) Is the ARPEGE-CLIMATE V4 global model able to reproduce the hydrological balance of the Mediterranean, Black and Caspian Seas, and to which confidence level? To address this question, individual components of the hydrologic balance are calculated from the present-day simulations and compared to a variety of data sources.

(2) Is this estimation (mean and variability) dependent on the resolution for present-climate? Specifically, is there a marked improvement in the simulation of the water budget components over the three basins with increased resolution. By evaluating runoff at a subbasin scale we can assess whether or not the performance of the model is dependent on resolution only over specific terrains, such as mountainous 
regions, or if increased resolution improves the overall performance of the simulation.

(3) Does the future evolution of the hydrological balance dependent on the resolution? Namely, do all three models produce similar future climate changes in terms of spatial pattern and intensity?

\section{Data and methodology}

In order to evaluate how well the models can estimate the hydrological budget over the Mediterranean, Black and Caspian Sea basins we divide the Mediterranean and Caspian basins into several sub-basins and perform a subbasin scale validation of runoff. Model runoff is estimated by spatially integrating the output runoff field over selected sub-basins. Our choice of sub-basins were determined largely upon the availability of observations. The Mediterranean is divided into ten sub-basins previously defined by Cruzado (1985) (hereafter referred to as the C85 subbasins) which are shown in Fig. 1 and listed in Table 1. Although the Black Sea is encompassed in the Mediterranean Sea basin, we consider it separately because the climatological characteristics are significantly different than that of the Mediterranean, and because we have additional data sources for the Black Sea. While the Mediterranean drainage basin covers more than $5 \times 10^{6} \mathrm{~km}^{2}$, much of this area is desert where a lot of the river discharge is lost through evaporation. In addition, the construction of the Aswan High Dam in the late 1960s drastically reduced the amount of discharge from the Nile River into the Mediterranean Sea. Thus the majority of runoff actually reaching the Mediterranean Sea comes from a land area of less than $1.5 \times 10^{6} \mathrm{~km}^{2}$ (Ludwig et al. 2009), of which the three largest river basins are the Rhone, Po and Ebro (not counting the Nile). In terms of their water discharge, these three rivers are the first, second and fifth largest rivers of the Mediterranean, respectively (Ludwig et al. 2009). The drainage area of the Black Sea basin is over $2 \times 10^{6} \mathrm{~km}^{2}$, extending far to the north and west of the Sea where the terrain is flat for the most part. Mountains lie to the south and east of the Black Sea, covering only a small fraction of the total drainage basin. While the Mediterranean region experiences wet-cold winters and dry-warm summers, the Black Sea basin receives most of its rainfall during the summer months.

The drainage basin of the Caspian Sea is vast, covering approximately $3.5 \times 10^{6} \mathrm{~km}^{2}$ and extending from 35 to $60 \mathrm{~N}$. For this study we divide the Caspian Sea basin into its three largest river basins: the Volga, the Kura and the Ural. Although more than 130 rivers flow into the Caspian Sea, these three river basins provide over $90 \%$ of the total runoff

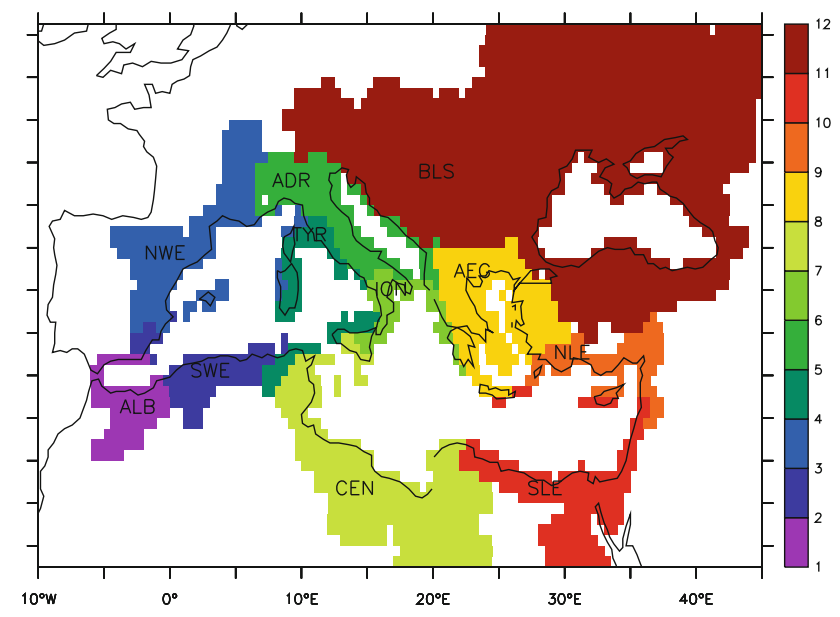

Fig. 1 Mediterranean sub-basins as defined by Cruzado (1985). ALB Alboran, SWE South-Western, NWE North Western, TYR Tyrrhenian, $A D R$ Adriatic, ION Ionian, CEN Central, AEG Aegean, NLE NorthLevantine, SLE South-Levantine, BLS Black Sea Land

Table 1 Area in $\mathrm{km}^{2} \times 10^{3}$ of individual basins and seas

\begin{tabular}{|c|c|c|c|c|}
\hline & HiRes & MedRes & LoRes & Observations \\
\hline \multicolumn{5}{|c|}{ C85 Mediterranean Sub-Basins } \\
\hline Alboran & 173 & 185 & 252 & $111^{\mathrm{a}}$ \\
\hline South-Western & 206 & 223 & 177 & $129^{\mathrm{a}}$ \\
\hline North-Western & 390 & 400 & 363 & $311^{\mathrm{a}}$ \\
\hline Tyrrhenian & 174 & 148 & 117 & $112^{\mathrm{a}}$ \\
\hline Adriatic & 316 & 310 & 336 & $235^{\mathrm{a}}$ \\
\hline Ionian & 77 & 93 & 31 & $68^{\mathrm{a}}$ \\
\hline Central & 1,380 & 1,360 & 1,351 & $1,135^{\mathrm{a}}$ \\
\hline Aegean & 342 & 322 & 328 & $286^{\mathrm{a}}$ \\
\hline North-Levantine & 171 & 173 & 186 & $131^{\mathrm{a}}$ \\
\hline South-Levantine & 3,529 & 3,545 & 3,455 & $3,010^{\mathrm{a}}$ \\
\hline Black Sea Land & 2,685 & 2,686 & 2,808 & $2,398^{\mathrm{a}}$ \\
\hline \multicolumn{5}{|c|}{ Individual Mediterranean River Basins } \\
\hline Ebro & 87 & 82 & 87 & $84^{\mathrm{b}}$ \\
\hline Rhone & 93 & 91 & 68 & $96^{\mathrm{b}}$ \\
\hline Po & 78 & 78 & 72 & $70^{\mathrm{b}}$ \\
\hline Danube & 814 & 812 & 814 & $807^{\mathrm{b}}$ \\
\hline \multicolumn{5}{|c|}{ Individual Caspian River Basins } \\
\hline Volga & 1,407 & 1,403 & 1,407 & $1,360^{\mathrm{b}}$ \\
\hline Kura & 181 & 186 & 186 & $205^{\mathrm{b}}$ \\
\hline Ural & 232 & 232 & 234 & $236^{\mathrm{b}}$ \\
\hline \multicolumn{5}{|l|}{ Seas } \\
\hline Black Sea & 456 & 466 & 344 & $460^{\mathrm{a}} 400^{\mathrm{d}}$ \\
\hline Mediterranean Sea & 2,517 & 2,516 & 2,601 & $2,500^{\mathrm{a}}$ \\
\hline Caspian sea & 383 & 396 & 367 & $376^{\mathrm{d}}$ \\
\hline
\end{tabular}

${ }^{\mathrm{a}}$ Ludwig et al. (2009), ${ }^{\mathrm{b}}$ Vorosmarty et al. (1998), ${ }^{\mathrm{c}}$ Georgievsky et al. (2003), ${ }^{\mathrm{d}}$ Stanev et al. (2000)

(Fig. 2). The Volga basin is by far the largest, contributing almost $80 \%$ of the total runoff into the Sea and covering most of the northern part of the basin where the terrain is 


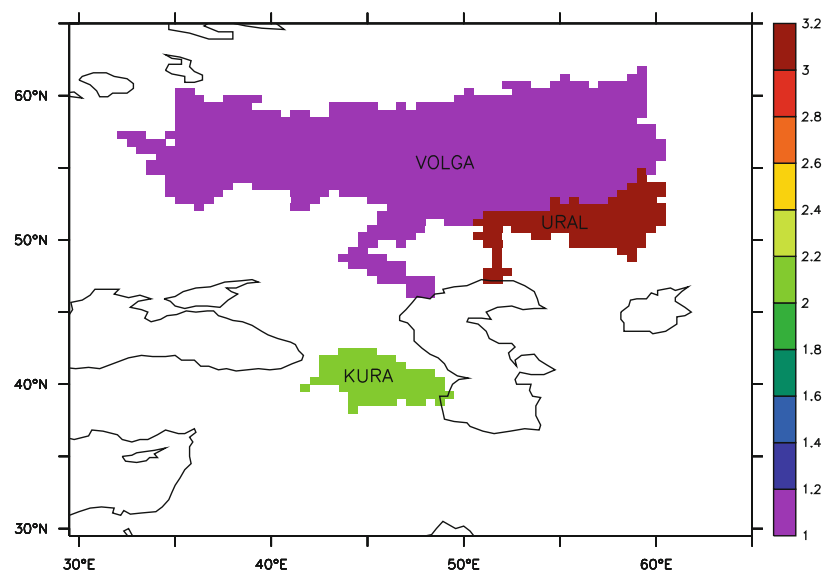

Fig. 2 The Volga, Ural and Kura river basins which contribute over $90 \%$ of the total runoff into the Caspian Sea

predominantly flat. Similarly the Ural basin covers a largely flat region, although much smaller than the Volga, extending from the southern end of the Ural mountains to the Caspian Sea. By contrast, the Kura basin covers a mostly mountainous region to the west of the Caspian Sea where the Caucasus mountains lie.

To validate the present-day components of the hydrological budget, comparisons between climatological averages as well as interannual variability are investigated. The total hydrological budget for the Mediterranean Sea is estimated as,

$P_{\mathrm{M}}-E_{\mathrm{M}}+R_{\mathrm{M}}$

where $P_{\mathrm{M}}$ and $E_{\mathrm{M}}$ represent precipitation and evaporation given in $\mathrm{mm}$ year $^{-1}$ over the Mediterranean Sea. $R_{\mathrm{M}}$ represents the total freshwater input to the Mediterranean Sea and is equal to,

$R_{\mathrm{M}}=R_{\mathrm{C} 85}+I_{\mathrm{B}}$

where $R_{\mathrm{C}} 85$ represents river runoff expressed as an area flux with respect to the Mediterranean Sea surface and is calculated as follows:

$R_{\mathrm{C} 85}=\left[\sum_{b=1}^{\text {nbasin }} F_{\mathrm{b}} \times \frac{A_{\mathrm{b}}}{A_{\mathrm{MS}}}\right]$

where nbasin is the number of sub-basins and $F_{\mathrm{b}}$ refers to the sub-basin's runoff flux expressed in $\mathrm{mm} \mathrm{year}^{-1} . A_{\mathrm{b}}$ is the area of the sub-basin and $A_{\mathrm{MS}}$ is the area of the Mediterranean Sea as defined by Ludwig et al. (2009). Because of discrepancies in the size of the basins, all model fluxes are standardized using the areas given by Ludwig et al. (2009) in Table 1. $I_{\mathrm{B}}$ represents the inflow from the Black Sea basin into the Mediterranean Sea through the Straits of Bosphorus and is estimated as follows:
$I_{\mathrm{B}}=\left(P_{\mathrm{B}}-E_{\mathrm{B}}+R_{\mathrm{B}}\right) \times\left(\frac{A_{\mathrm{BS}}}{A_{\mathrm{MS}}}\right)$

where $P_{\mathrm{B}}, E_{\mathrm{B}}$ and $R_{\mathrm{B}}$ represent the precipitation, evaporation and runoff fluxes over the Black Sea, respectively, and $A_{\mathrm{BS}}$ is the area of the Black Sea. For the Caspian Sea, the total hydrological budget is estimated as,

$P_{\mathrm{C}}-E_{\mathrm{C}}+R_{\mathrm{C}}$

where $P_{\mathrm{C}}, E_{\mathrm{C}}$ and $R_{\mathrm{C}}$ represent the precipitation, evaporation and runoff fluxes over the Caspian Sea.

To explore changes in the hydrologic balance of the Mediterranean, Black and Caspian sea basins occurring under anthropogenically induced projected mid-century climate change (IPCC A2 scenario), we compare three future simulations for the period 2046-2070 to the corresponding present-day simulations discussed above. Future changes that occur in temperature, precipitation and evaporation fields as well as in the individual hydrological budget components over the regions of interest are discussed. Following is a description of the CNRM-GCM ARPEGE which was used to perform all of the simulations in this study and the observational data used for the present-day validation.

\subsection{Model description}

The model used is Arpege-Climat 4.6, which has been derived from cycle 24 of the meteorological forecast model Arpege/IFS used by Météo-France, the French Meteorological service, and ECMWF for operational short, medium and seasonal-range forecasting. It uses a semi-lagrangian advection with a two time-level discretization. The vertical discretization uses 31 vertical levels located mainly in the troposphere. The time step is $15 \mathrm{~min}$. Three horizontal resolutions are defined with respectively 64,160 and 360 latitude circles. The number of longitudes varies according to latitude to maintain grid isotropy (the maximum number being 128, 320 and 720, respectively). The upper-air dynamical fields are expanded on a series of spherical harmonics with a triangular truncation to wavenumber $n=63,159$ and 359 , respectively. The convection scheme is derived from the mass-flux scheme with moisture convergence closure described by Bougeault (1985). The Morcrette (1990) scheme is used to calculate the radiation, which includes the effect of four greenhouse gases $\left(\mathrm{CO}_{2}\right.$, $\mathrm{CH}_{4}, \mathrm{~N}_{2} \mathrm{O}$ and $\mathrm{CFC}$ ) in addition to water vapor and ozone, and of five aerosol types (land, sea, urban, desert and sulfate) in addition to background aerosols. The cloud-precipitation-vertical diffusion scheme uses the statistical approach of Ricard and Royer (1993). The soil scheme consists of a four-layer diffusion scheme for temperature 
and the ISBA soil vegetation scheme (Douville et al. 2000) for the hydrological cycle. Runoff is calculated as the water overflow in the surface and deep soil layers. Representation of orographic gravity wave drag has been improved, with respect to the scheme used in version 1 (Déqué et al. 1994), by the addition of mountain blocking and the lift effect (Lott and Miller 1997; Lott 1999). More details on the model can be found at: http://www.cnrm.meteo.fr/ gmgec/site_engl/arpege/arpege_en.htm.

For the present-day simulations, SSTs are taken from the ERA40 dataset (Uppala et al. 2005). In the future climate simulations, SSTs are estimated to be present-day values plus a perturbation. This perturbation is calculated as the difference between future and present-day SSTs from simulations performed by the ARPEGE/OPA coupled Atmosphere-Ocean GCM for the Intergovernmental Panel on Climate Change Assessment Report 4 (IPCC-AR4). The model horizontal resolution was TL63 (about $300 \mathrm{~km}$ ) for the atmosphere and $2^{\circ}$ for the ocean in these simulations. More model details can be found at: http://www-pcmdi. llnl.gov/ipcc/about_ipcc.ph. It should also be noted that a bias correction factor has been applied to the future scenario SSTs. This correction factor is calculated as,

$$
\begin{aligned}
\operatorname{SST} 2(\mathrm{~m}, \mathrm{y})= & \text { SST1 }(\mathrm{m}, \mathrm{y}) \\
& +\left[\operatorname{MSST} \_\operatorname{Era}(\mathrm{m})-\operatorname{MSST} \_\operatorname{Arp}(\mathrm{m})\right]
\end{aligned}
$$

where $\mathrm{m}$ represents the month and y the year. SST1 and SST2 are the corrected and uncorrected SSTs, respectively. MSST_Era and MSST_Arp are averages for the period 1958-2000 from ERA40 and ARPEGE/OPA, respectively.

\subsection{Data}

To validate the models' temperature and precipitation fields we use the global half degree precipitation and temperature datasets of the Climate Research Unit (CRU) of the University of East Anglia (New et al. 2002). The CRU data cover the period 1979-2002 and provide a good present-day climatology. As with most observational datasets, there are some inherent biases in the CRU data. The data are uncorrected for gauge undercatch, therefore estimates of precipitation can be largely underestimated, especially in mountainous regions and when there is snowfall. In addition, the data have a low elevation station bias, thus temperature in mountainous regions are likely to be overestimated.

A variety of data sources are used to validate runoff and $P-E$ over the Mediterranean basin. For runoff over the Mediterranean basin we use the estimates of Ludwig et al. (2009) for the period 1960-2000. These authors compiled time-series of 37 Mediterranean and Black Sea rivers utilizing several different sources (Medhycos 2001), the global river discharge database RivDIS (Vorosmarty et al.
1998) and the Hydro database (French Ministry of Environment 2006). Whenever the observations correspond to gauging stations close to the river mouths, river runoff data were aggregated to the sub-basin scale as defined by Cruzado (1985). For the parts of the drainage basins which were not covered by observations, runoff was estimated by conversion of the CRU P and T climatologies into water discharge based on a simple hydrological algorithm which is based on the empirical formula of Pike (1964) and found to give realistic estimations for average runoff depth in Mediterranean rivers (Ludwig et al. 2009). Pike (1964) proposed to calculate the mean annual runoff ratio $(\mathrm{RR}=$ runoff/precipitation) as a function of the ratio of the mean annual precipitation total (APPT) over the mean annual potential evapotranspiration (APE):

$\mathrm{RR}=1-\left[\frac{1}{\left(1+\left(\frac{\mathrm{APPT}}{\mathrm{APE}}\right)^{2}\right)^{0.5}}\right]$

According to Holdridge (1959), APE can be derived in a first order approximation as a linear function of the mean annual biotemperature $(\mathrm{ABT} ; \mathrm{APE}=\mathrm{ABT} \times 58.93)$, which is the average of all monthly temperatures for which negative values were set to zero. A theoretical runoff (Q-Pike) can consequently be obtained by multiplication of RR and APPT:

$$
\mathrm{Q}-\mathrm{Pike}=\mathrm{RR} \times \mathrm{APPT}
$$

The so-created freshwater budgets correspond to about one-third of observations and two-thirds of purely modelled values for the Mediterranean drainage basin. In the case of the Black Sea, the large rivers are much more important in the total budgets and almost $80 \%$ of the budgets are constrained by observations. This is important because in the drainage basin of the Black Sea Q-Pike is probably less adapted to estimate water discharge (Ludwig et al. 2009).

The resulting freshwater budgets estimate by Ludwig et al. (2009) correspond to the entire continental area that is drained into the Mediterranean and Black Sea and are used to validate runoff from the climate model outputs in this study. Additional data sources for the Black Sea basin compiled by Stanev et al. (2000) and Kara et al. (2008) are also used.

An important point when establishing the river freshwater budget estimates for the Mediterranean is how to deal with the Nile River. After the construction of the Aswan Dam in 1964, the runoff from the Nile basin into the Mediterranean Sea was drastically reduced. This could have had an impact on the overall freshwater budgets of the Mediterranean Sea, however, there is a great deal of 
uncertainty regarding the amount of reduction in runoff caused by the dam. Some studies have estimated a more than $90 \%$ reduction in runoff after the damming (Poulos and Drakpooulos 2001), while others claim the reduction is less because the pre-damming value at the river mouth was probably only slightly more than half of the discharge at Aswan (Nixon 2003). Given the uncertainty regarding the amount of reduction in runoff caused by the dam, coupled to the fact that the models do a poor job of estimating precipitation in the tropical southern part of the basin as will be demonstrated in the following section, we chose to supplement the models' estimate of runoff from the Nile basin with the estimate of Ludwig et al. (2009), $7 \mathrm{~mm}$ year $^{-1}$, in order to complete our estimation of the total hydrological budget. For the future calculations, we calculate the change in the model's estimate of present-day and future Nile runoff, then apply this percentage change to the value used for in the present-day calculations $(7 \mathrm{~mm}$ year $^{-1}$ ).

The literature provides numerous estimates of total Mediterranean freshwater runoff and $P-E$ that have been made using a variety of different methods and data sources (Tixeront 1970; Bethoux 1979; Tomczak and Godfrey 1994; Boukthir and Barnier 2000; Mariotti and Struglia 2002; Struglia et al. 2004). Given the many different sources of error in obtaining these estimates, it is not surprising that the range of values is quite large. Nonetheless, it provides us a guide in which to base our validation. Estimates of inflow and outflow through the Gibraltar Strait provide us with an additional source of validation. The only outlet of the Mediterranean Sea is through the Gibraltar Strait to the Atlantic Ocean, thus the long-term hydrological budget over the entire basin should be approximately equal to the net water flux at the Gibraltar Strait. This allows us to utilize measurements of the net water flux at the Gibraltar Strait to further validate the basin's hydrological balance (Garcia-Lafuente et al. 2007; Baschek et al. 2001; Bryden et al. 1994; Candela 2001; Tsimplis and Baker 2000).

For the Caspian Sea we use time series of inflow and water balance components for the Volga, Kura, and Ural river basins that have been compiled by the Russian State Hydrological Institute (SHI) (Georgievsky et al. 2003; Shiklomanov et al. 2003). For $P-E$ over the Sea, we use the annual values calculated as a residual of the Sea's water balance.

\section{Present-day validation}

We begin this section by presenting a comparison of present-day temperature and precipitation climatological fields between the models' output and the CRU observations. We focus on winter (DJF) and summer (JJA) climatological seasons based on the time period 19792002. Finally, we compare components of the basins' hydrological budget calculated from the models' output to observed estimates.

\subsection{The Mediterranean and Black Seas region}

Spatial maps of the bias between the models and the observations are presented in Figs. 3 and 4. For a more quantitative assessment, modelled and observed precipitation and temperature averages, as well as standard deviations, during the winter and summer months for individual sub-basins are also presented in Tables 2 and 3. During the winter season (DJF), the HiRes model simulates temperature reasonably well across the domain, however, there is a cold bias $\left(2-4^{\circ} \mathrm{C}\right)$ around some parts of the Mediterranean basin, namely Spain, northwestern Africa, and significant portions of southern Italy and Greece, which is comparable in magnitude to biases others have found in the region (Gibelin and Déqué 2003; Jacob et al. 2007; Giorgi et al. 2004). Contrarily, a slight warm bias exists in the Caucasus mountains east of the Black Sea (perhaps due to deficiencies in large-scale dynamics in the model or more likely representation of topography). The spatial pattern of the temperature biases are similar in the MedRes model, however the warm bias in the Caucasus mountains is more pronounced. In addition, slight warm biases begin to appear in much of the mountainous regions in the basin, most notably in the Alps, the Apennines in central Italy and the Dinaric Alps along the Croatian coast. This is certainly due to the under-representation of topography in the model. The LoRes model indicates a similar warming trend with decreased resolution, thus much of the cold biases present in the other models have disappeared while the warm biases in the mountainous regions are considerably more pronounced $\left(2-8^{\circ} \mathrm{C}\right)$.

The HiRes model also simulates temperature well across the domain during the summer season (JJA). There are a couple of notable exceptions, namely a significant cold bias $\left(6-8^{\circ} \mathrm{C}\right)$ exists in the southwestern region of the Black Sea (Caucasus mountains), which is likely a result of too much precipitation in this region, and a slight warm bias $\left(2-4^{\circ} \mathrm{C}\right)$ in the Saharan desert of Egypt and Libya. In the MedRes and LoRes models these biases become more pronouced as resolution decreases. In addition, the lower resolution models (MedRes and LoRes) have warm biases in the mountainous regions, particularly in the Alps where biases are between 6 and $8^{\circ} \mathrm{C}$.

With regard to the sub-basin averages presented in Tables 2 and 3, we find similar results showing that as resolution decreases the model becomes warmer. The spatial maps show that this is mostly the case in 
Fig. 3 Difference plots (model minus observations) between modelled and observed presentday temperature $\left({ }^{\circ} \mathrm{C}\right)$ climatology over the Mediterranean and Black Sea basins for the HiRes, MedRes and LoRes models during winter $(D J F)$ and summer $(J J A)$ seasons
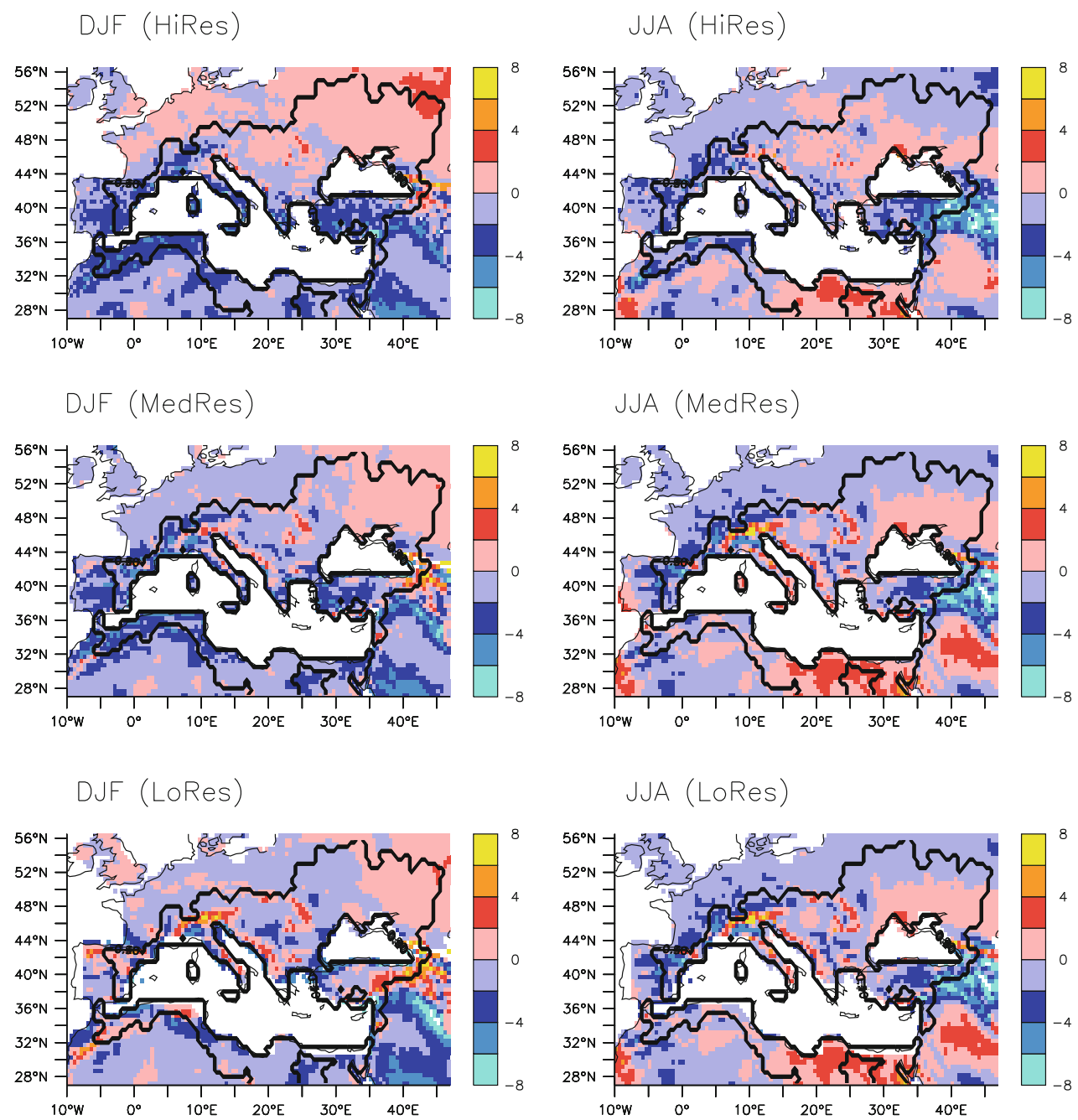

mountainous regions where we expect topography to be under-represented in the lower resolution models. During the winter, the models have a cold bias in all of the subbasins, with the highest resolution model having the largest bias. However, we should keep in mind that the ground based observations, such as the CRU dataset, have a low elevation station bias thus the models' biases may not be as large in reality. In several of the sub-basins during the summer, we find that while the HiRes model still has a slight cold bias, the LoRes model has a slight warm bias and the MedRes model falls somewhere in between. In general, the models have too much interannual variability during the winter. One notable exception is the Black Sea basin where all the models have a smaller standard deviation than the observed. In almost half of the sub-basins (SWE, NWE, TYR, ADR and ION), the interannual variability is clearly better represented by the HiRes model. The interannual variability is better represented by all models during the summer, especially the HiRes model.
Precipitation is simulated generally well in the HiRes model during the winter season except for a positive bias over eastern France and Germany. In the MedRes model, the magnitude of this positive bias decreases somewhat but is still prominent over the same spatial extent, whereas in the LoRes model the area of the bias is considerably reduced. Negative biases in mountainous regions as well as over peninsulas and islands, such as in southern Italy, increase significantly in the LoRes model. Precipitation biases are slightly larger during the summer season. Significant positive biases exist over large parts of Spain, France and Germany as well as to the southeast of the Black Sea. These biases increase as resolution decreases.

With regard to the sub-basin averages, during the winter all models have a negative bias in most of the sub-basins, with the HiRes model coming closest to the observed values. However, during the summer the contrary is true in that all models tend to have positive biases, where the HiRes model produces the most precipitation and thus has 
Fig. 4 Difference plots (model minus observations) between modelled and observed presentday precipitation $\left(\mathrm{mm} \mathrm{day}^{-1}\right)$ climatology over the Mediterranean and Black Sea basins for the HiRes, MedRes and LoRes models during winter $(D J F)$ and summer (JJA) seasons
DJF (HiRes)

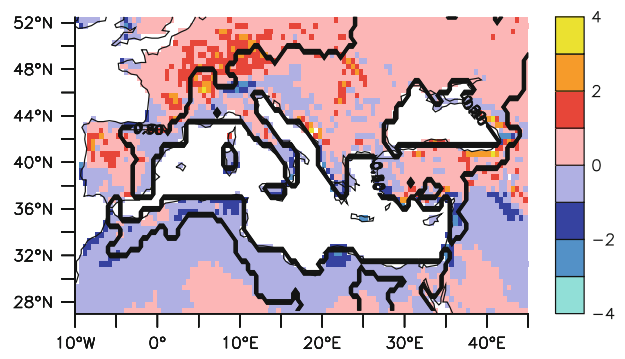

DJF (MedRes)

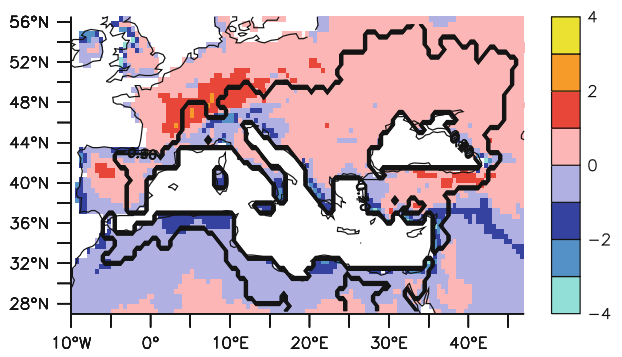

DJF (LoRes)

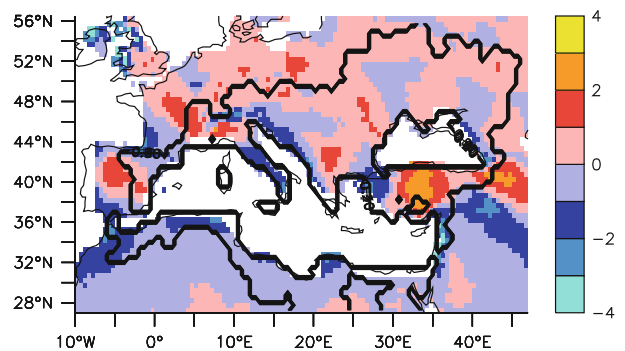

JJA (HiRes)

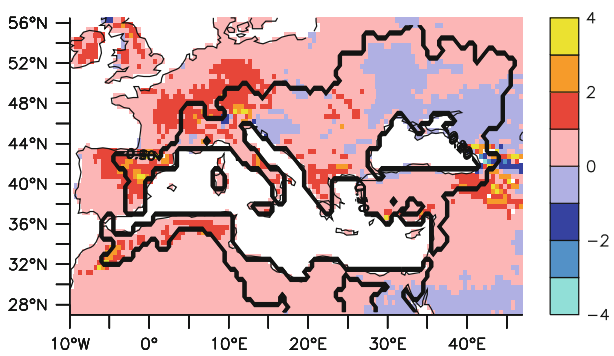

JJA (MedRes)

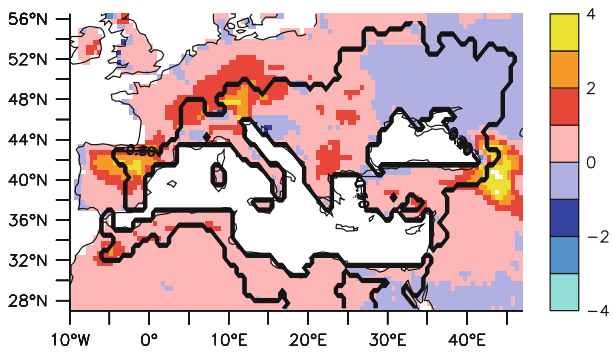

JJA (LoRes)

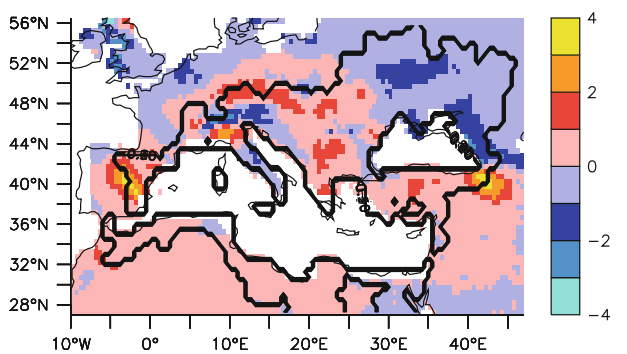

Table 2 Average modelled and observed temperature $\left({ }^{\circ} \mathrm{C}\right)$ and precipitation (mm day ${ }^{-1}$ ) during winter (DJF) for the Mediterranean sub-basins

\begin{tabular}{|c|c|c|c|c|c|c|c|c|}
\hline & \multicolumn{4}{|l|}{ Temperature } & \multicolumn{4}{|l|}{ Precipitation } \\
\hline & HiRes & MedRes & LoRes & Obs & HiRes & MedRes & LoRes & Obs \\
\hline Alboran & $5.9(0.90)$ & $6.8(0.76)$ & $8.6(1.13)$ & $9.3(0.65)$ & $1.06(0.42)$ & $0.92(0.52)$ & $0.39(0.29)$ & $1.52(0.67)$ \\
\hline South-Western & $5.3(0.79)$ & $5.8(0.88)$ & $7.1(1.15)$ & $9.1(0.66)$ & $1.20(0.44)$ & $0.88(0.33)$ & $0.59(0.27)$ & $1.79(0.45)$ \\
\hline North-Western & $2.4(0.79)$ & $2.3(1.11)$ & 3.7 (1.10) & $5.5(0.71)$ & $2.13(0.53)$ & $1.94(0.50)$ & $1.84(0.57)$ & $1.92(0.52)$ \\
\hline Tyrrhenian & $5.1(0.62)$ & $5.7(0.84)$ & $6.3(0.97)$ & $9.0(0.56)$ & $1.62(0.46)$ & $1.30(0.28)$ & $0.83(0.27)$ & $2.27(0.51)$ \\
\hline Adriatic & $0.7(0.74)$ & $0.9(1.02)$ & $1.6(0.96)$ & $3.3(0.74)$ & $2.60(0.74)$ & $2.29(0.54)$ & $2.08(0.45)$ & $2.65(0.73)$ \\
\hline Ionian & $4.3(0.73)$ & $5.5(0.73)$ & $5.5(1.01)$ & $8.9(0.58)$ & $2.15(0.64)$ & $1.72(0.47)$ & $1.54(0.44)$ & $3.11(0.78)$ \\
\hline Central & $11.9(0.67)$ & $12.5(0.60)$ & $12.3(0.93)$ & 13.9 (1.14) & $0.13(0.04)$ & $0.10(0.03)$ & $0.06(0.03)$ & $0.45(0.10)$ \\
\hline Aegean & $1.6(0.90)$ & $1.3(0.78)$ & $1.6(1.06)$ & $5.6(0.71)$ & $2.32(0.60)$ & $2.16(0.54)$ & $1.89(0.40)$ & $2.68(0.73)$ \\
\hline North-Levantine & $1.6(0.87)$ & $2.2(0.64)$ & $3.2(0.93)$ & $6.2(1.21)$ & $2.64(0.55)$ & $1.99(0.39)$ & $2.00(0.48)$ & $2.98(0.77)$ \\
\hline South-Levantine & $19.2(0.55)$ & $19.5(0.44)$ & $20.3(0.60)$ & $21.8(0.60)$ & $2.92(0.23)$ & $2.72(0.21)$ & $2.42(0.14)$ & $0.64(0.14)$ \\
\hline Black Sea & $-2.1(0.86)$ & $-2.5(0.91)$ & $-2.2(0.84)$ & $-1.9(1.16)$ & $1.95(0.31)$ & $1.90(0.26)$ & $1.77(0.22)$ & $1.55(0.25)$ \\
\hline
\end{tabular}

Standard deviation is given in parenthesis

the largest bias. In most of the sub-basins, the interannual variability during the winter is represented reasonably well by the HiRes model, whereas the MedRes and LoRes models tend to underestimate the variability. During the summer, the models do not perform as well and have a tendency to overestimate the interannual variability. 
Table 3 Average modelled and observed temperature $\left({ }^{\circ} \mathrm{C}\right)$ and precipitation (mm day ${ }^{-1}$ ) during summer (JJA) for the Mediterranean sub-basins

\begin{tabular}{|c|c|c|c|c|c|c|c|c|}
\hline & \multicolumn{4}{|l|}{ Temperature } & \multicolumn{4}{|l|}{ Precipitation } \\
\hline & HiRes & MedRes & LoRes & Obs & HiRes & MedRes & LoRes & Obs \\
\hline Alboran & $22.7(0.65)$ & $23.9(0.50)$ & $28.9(0.73)$ & $24.4(0.68)$ & $1.23(0.40)$ & $1.00(0.51)$ & $0.72(0.48)$ & $0.21(0.14)$ \\
\hline South-Western & $22.8(0.74)$ & $24.2(0.65)$ & $26.7(0.70)$ & $24.9(0.76)$ & $1.26(0.39)$ & $1.02(0.40)$ & $0.69(0.36)$ & $0.36(0.18)$ \\
\hline North-Western & $17.8(0.65)$ & $18.3(0.75)$ & $20.5(1.05)$ & $20.3(0.65)$ & $2.92(0.43)$ & $2.93(0.42)$ & $2.42(0.41)$ & $1.52(0.42)$ \\
\hline Tyrrhenian & $21.6(0.74)$ & $23.3(0.78)$ & $24.6(0.53)$ & $23.6(0.66)$ & $1.50(0.43)$ & $1.13(0.39)$ & $0.59(0.19)$ & $0.60(0.25)$ \\
\hline Adriatic & $17.9(0.70)$ & $18.8(0.75)$ & $20.2(0.56)$ & $19.8(0.67)$ & $3.21(0.57)$ & $2.96(0.57)$ & $2.66(0.27)$ & $2.24(0.42)$ \\
\hline Ionian & $21.1(0.82)$ & $23.6(0.62)$ & $23.9(0.61)$ & $23.5(0.68)$ & $1.46(0.47)$ & $0.88(0.32)$ & $0.93(0.31)$ & $0.49(0.20)$ \\
\hline Central & $29.4(0.58)$ & $29.9(0.46)$ & $30.4(0.61)$ & $29.2(0.61)$ & $0.19(0.10)$ & $0.12(0.05)$ & $0.07(0.03)$ & $0.06(0.02)$ \\
\hline Aegean & $20.9(0.79)$ & $21.4(0.65)$ & $23.7(0.68)$ & $22.9(0.76)$ & $1.52(0.42)$ & $1.55(0.36)$ & $1.50(0.37)$ & $0.72(0.24)$ \\
\hline North-Levantine & $20.6(0.53)$ & $22.3(0.59)$ & $25.1(0.52)$ & $24.2(1.00)$ & $1.02(0.29)$ & $0.80(0.30)$ & $0.59(0.23)$ & $0.31(0.13)$ \\
\hline South-Levantine & $24.2(0.39)$ & $25.2(0.36)$ & $27.0(0.53)$ & $26.7(0.29)$ & $4.85(0.36)$ & $4.51(0.30)$ & $3.86(0.79)$ & $2.99(0.35)$ \\
\hline Black Sea & 18.7 (1.09) & $18.9(0.58)$ & $20.9(0.88)$ & $19.4(0.76)$ & $2.40(0.32)$ & $2.47(0.43)$ & $2.01(0.18)$ & $2.13(0.22)$ \\
\hline
\end{tabular}

Standard deviation is given in parenthesis

\subsection{The Caspian Sea region}

Spatial maps of the bias between the models and the observations over the Caspian basin are presented in Figs. 5 and 6. Modelled and observed precipitation and temperature averages (and standard deviations) during the winter and summer months for the individual basins are also presented in Tables 4 and 5. In the winter season, there is a general slight warm bias north of $40^{\circ} \mathrm{N}$ and a slight cool bias to the south. These biases are slightly more pronounced in the HiRes simulation. However, the HiRes model noticeably decreases the biases in the mountainous areas to the southwest of the Sea. Also during the summer, increased resolution decreases biases associated with topography, as well as the warm bias in the desert area east of the Sea present in lower resolution simulations. Temperature averages over the individual river basins also show that the models tend to have a slight warm bias during the winter and a slight cold bias during the summer.

Precipitation is simulated well across the basin by the HiRes model except for some noticeable biases in the mountainous regions south and west of the Sea, particularly during the summertime. Contrary to what is expected, decreased resolution actually increases the precipitation biases over mountainous regions, notably over the Caucasas mountains in the Kura basin in the MedRes model, and to a lesser extent in the LoRes model. As a result, the LoRes and MedRes models have significant positive biases in this region, especially during the summer.

Overall we see a general improvement in the simulation of temperature and precipitation across the Mediterranean, Black and Caspian basins with increased horizontal resolution. This is largely due to a more accurate representation of the topography and large-scale circulation, which is necessary for simulating the water budget components within a hydrological basin.

\section{The hydrologic balance}

\subsection{The Mediterranean and Black Seas region}

Runoff values (both the present-day climatological average and interannual variability) for the C85 sub-basins (which include the total direct freshwater input into the Mediterranean Sea except that which enters from the Black Sea basin via the Dardanelles Strait), the four largest individual river basins in the Mediterranean (Ebro, Po, Rhone and Danube) and the Black sea are presented in Table 6. Also presented in Table 6 are the calculations for $P-E$ over the Mediterranean and Black seas, followed by estimates of the complete hydrologic budget.

Resolution has little impact on the Black Sea basin's estimated runoff which is an expected result given the flatness of the terrain. The models' runoff estimates are very close (within 4\%) to observed estimates of Ludwig et al. (2009) and Stanev et al. (2000). Although when compared to the estimate of Vorosmarty et al. (1998), the models overestimate by $40-45 \%$, however their observed estimate only takes into account the largest rivers in the basin which may partly explain why it is much lower that the other observed estimates. Contrarily, $P_{\mathrm{B}}-E_{\mathrm{B}}$ over the Sea is largely overestimated in the models, especially in the HiRes model which estimates an average $P_{\mathrm{B}}-E_{\mathrm{B}}$ of $-365 \mathrm{~mm}$ year $^{-1}$ compared to the observed $-125 \mathrm{~mm}$ year $^{-1}$ (Stanev et al. 2000). The MedRes and LoRes estimates are also very high, more than double the observed estimate. When the estimate of total freshwater input $\left(P_{\mathrm{B}}-E_{\mathrm{B}}+R_{\mathrm{B}}\right)$ from the Black Sea basin into the 
Fig. 5 Difference plots (model minus observations) between modelled and observed presentday temperature $\left({ }^{\circ} \mathrm{C}\right)$ climatology over the Caspian Sea basin for the HiRes, MedRes and LoRes models during winter $(D J F)$ and summer $(J J A)$ seasons
DJF (HiRes)

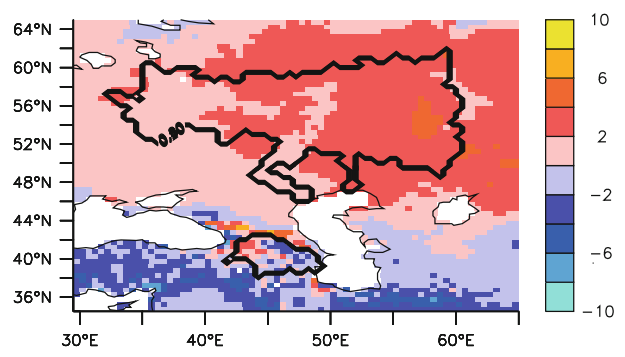

DJF (MedRes)

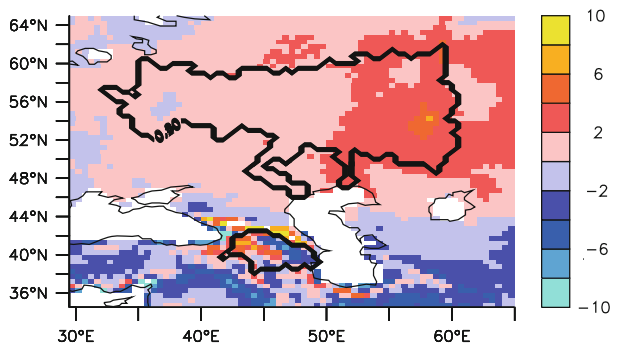

DJF (LoRes)

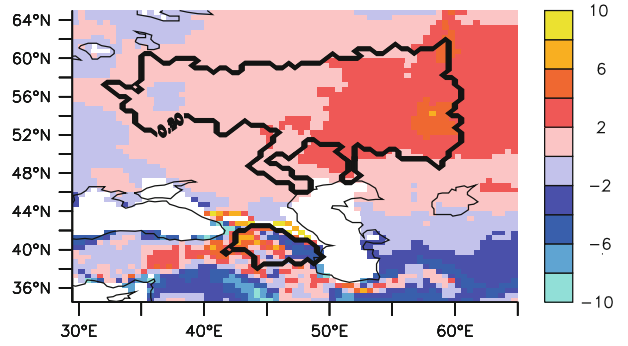

JJA (HiRes)

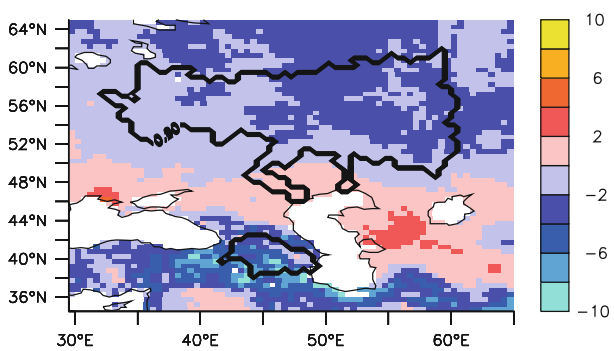

JJA (MedRes)

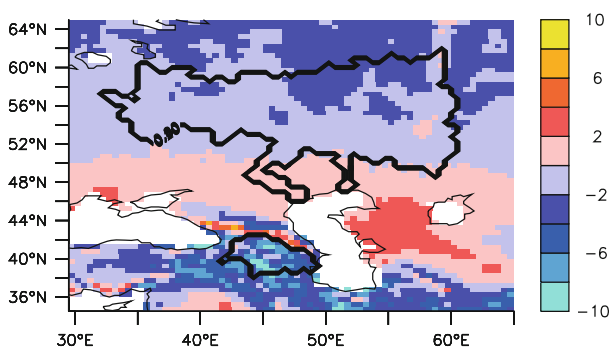

JJA (LoRes)

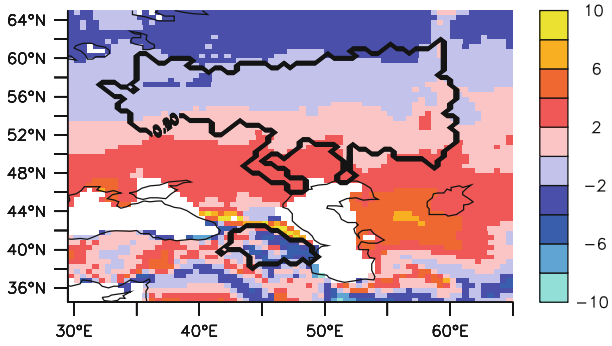

Mediterranean Sea is considered, all model estimates fall within the range of observed uncertainty (408-750 mm year $\left.^{-1}\right)$.

In all of the C85 sub-basins, the models consistently underestimate runoff in comparison to the observations. In nearly all of the cases, as resolution decreases the models' estimates of runoff decrease, thus the HiRes model produces the best overall estimates. In sub-basins where there is little precipitation and where the models tend to underestimate precipitation, such as the SWE, TYR and CEN sub-basins around northern Africa and western Italy, the models' estimates of runoff are less than half the observed. The ALB, NWE, ADR and NLE sub-basins produce the best estimates in which the HiRes model has biases of -13 , $3,-12$ and $-7 \%$. Runoff is underestimated in the ION and AEG basins which include Greece and parts of Turkey by -25 and $-24 \%$, respectively, by the HiRes model where precipitation is also underestimated. In the ION and AEG basins the MedRes and LoRes models perform much worse, underestimating runoff by approximately 75 and $40 \%$, respectively. When the total freshwater input to the
Mediterranean Sea is considered $\left(R_{\mathrm{C}} 85\right)$, only the HiRes model's estimate of $121 \mathrm{~mm} \mathrm{year}^{-1}$ is within the range of the observed uncertainty (100-141 $\mathrm{mm}_{\text {year }}{ }^{-1}$ ), while the MedRes and LoRes models both underestimate the freshwater input ( 88 and $84 \mathrm{~mm}_{\text {year }}{ }^{-1}$, respectively).

Because there is often a large discrepancy between modelled and observed precipitation due to deficiencies in both the models and observations as mentioned previously, it is worthwhile to also consider the runoff ratio quantity $(R / P)$ for each sub-basin in order to better assess how well the models translate precipitation into runoff. We would expect this ratio to be higher where precipitation is better simulated, such as mountainous regions in the HiRes model where the topography is better represented and orographic precipitation is better simulated. In such cases when the ground is saturated, the increased precipitation will translate into more overland runoff resulting in a higher $R / P$ ratio. This is indeed the case when we compare the runoff ratio for both the models and observations for the C85 subbasins in Table 7 . The observed runoff ratios are calculated using the observed runoff values from Ludwig et al. (2009) 
Fig. 6 Difference plots (model minus observations) between modelled and observed presentday precipitation $\left(\mathrm{mm} \mathrm{day}^{-1}\right)$ climatology over the Caspian Sea basin for the HiRes, MedRes and LoRes models during winter $(D J F)$ and summer $(J J A)$ seasons
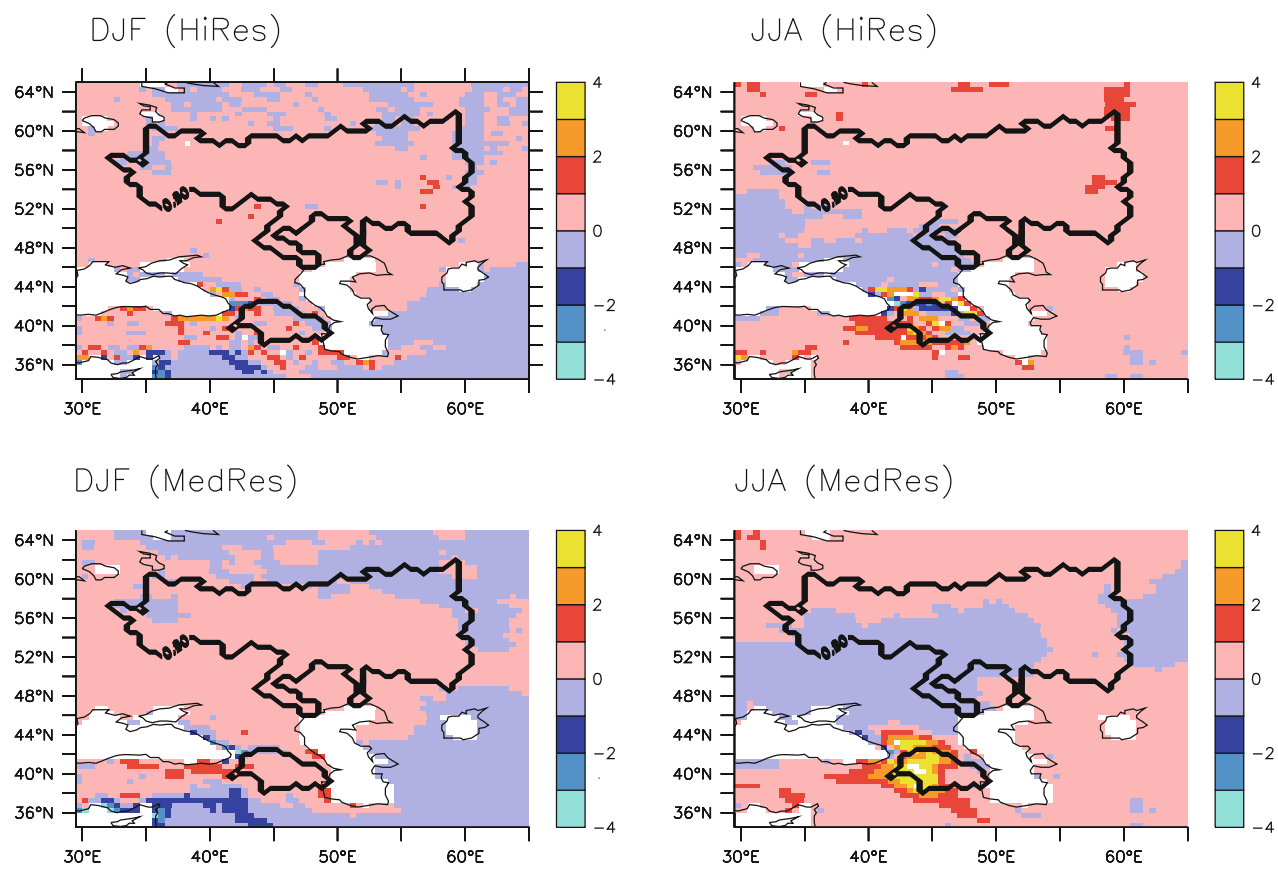

DJF (LoRes)

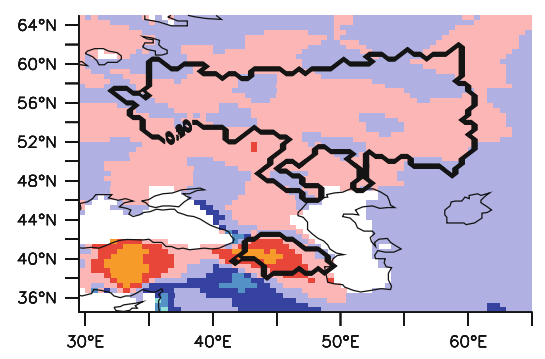

JJA (LoRes)

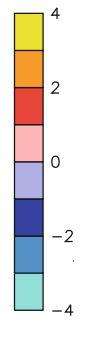

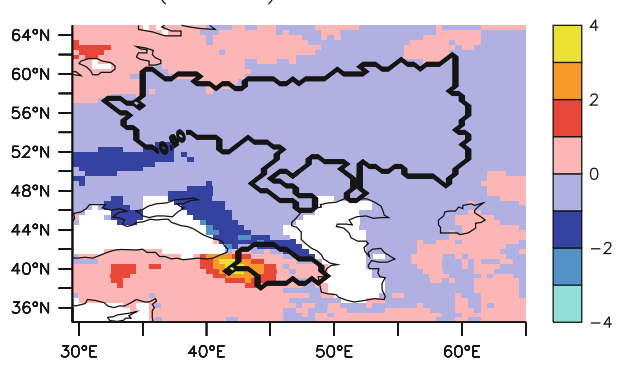

Table 4 Average modelled and observed temperature $\left({ }^{\circ} \mathrm{C}\right)$ and precipitation $\left(\mathrm{mm} \mathrm{day}^{-1}\right.$ ) during winter (DJF) for Caspian Sea basins

\begin{tabular}{|c|c|c|c|c|c|c|c|c|}
\hline & \multicolumn{4}{|l|}{ Temperature } & \multicolumn{4}{|c|}{ Precipitation } \\
\hline & HiRes & MedRes & LoRes & Obs & HiRes & MedRes & LoRes & Obs \\
\hline Volga & $-7.7(1.14)$ & $-8.4(1.43)$ & $-8.2(1.44)$ & $-10.0(1.90)$ & $1.58(0.27)$ & $1.43(0.27)$ & $1.39(0.23)$ & $1.27(0.23)$ \\
\hline Kura & $-3.3(0.81)$ & $-2.7(0.56)$ & $-2.0(0.77)$ & $-3.0(1.30)$ & $1.24(0.23)$ & $1.32(0.25)$ & $2.12(0.42)$ & $0.90(0.26)$ \\
\hline Ural & $-8.9(1.54)$ & $-8.9(1.44)$ & $-8.7(1.29)$ & $-11.8(1.97)$ & $1.17(0.37)$ & $1.04(0.26)$ & $0.96(0.24)$ & $0.82(0.22)$ \\
\hline
\end{tabular}

Standard deviation is given in parenthesis

Table 5 Average modelled and observed temperature $\left({ }^{\circ} \mathrm{C}\right)$ and precipitation $\left(\mathrm{mm} \mathrm{day}^{-1}\right)$ during summer $(\mathrm{JJA})$ for the Caspian Sea basins

\begin{tabular}{|c|c|c|c|c|c|c|c|c|}
\hline & \multicolumn{4}{|l|}{ Temperature } & \multicolumn{4}{|c|}{ Precipitation } \\
\hline & HiRes & MedRes & LoRes & Obs & HiRes & MedRes & LoRes & Obs \\
\hline Volga & $16.2(1.16)$ & $16.6(1.00)$ & $17.8(1.42)$ & $18.1(1.11)$ & $2.58(0.55)$ & $2.19(0.32)$ & $1.70(0.36)$ & $2.18(0.38)$ \\
\hline Kura & $16.6(0.70)$ & $16.4(0.65)$ & $19.5(0.95)$ & $20.9(0.97)$ & $2.16(0.42)$ & $3.55(0.52)$ & $2.06(0.39)$ & $1.47(0.39)$ \\
\hline Ural & $19.1(1.32)$ & $20.3(1.23)$ & $22.6(1.48)$ & $20.8(1.31)$ & $1.52(0.56)$ & $1.21(0.34)$ & $0.88(0.27)$ & $1.16(0.28)$ \\
\hline
\end{tabular}

Standard deviation is given in parenthesis 
Table 6 Modelled and observed average runoff values in the Mediterranean Sea basin in mm year ${ }^{-1}$

\begin{tabular}{|c|c|c|c|c|}
\hline & HiRes & MedRes & LoRes & Observations \\
\hline \multicolumn{5}{|l|}{ C85 Basins } \\
\hline Alboran & $32(59)$ & $18(146)$ & 0 & $37(87)^{\mathrm{a}}$ \\
\hline South-Western & $14(127)$ & 3 (129) & 0 & $71(47)^{\mathrm{a}}$ \\
\hline North-Western & $298(19)$ & $239(23)$ & $207(24)$ & $289(18)^{\mathrm{a}}$ \\
\hline Tyrrhenian & $79(52)$ & $37(71)$ & 0 & $164(33)^{\mathrm{a}}$ \\
\hline Adriatic & $468(22)$ & $337(18)$ & $356(23)$ & $530(16)^{\mathrm{a}}$ \\
\hline Ionian & $123(50)$ & $36.5(88)$ & $41(71)$ & $165(35)^{\mathrm{a}}$ \\
\hline Central & $0.3(171)$ & 0 & 0 & $4(41)^{\mathrm{a}}$ \\
\hline Aegean & $137(44)$ & $102(57)$ & $104(43)$ & $179(26)^{\mathrm{a}}$ \\
\hline North-Levantine & $144(27)$ & $54(74)$ & $67(68)$ & $156(38)^{\mathrm{a}}$ \\
\hline South-Levantine & $7^{\mathrm{a}}$ & $7^{\mathrm{a}}$ & $7^{\mathrm{a}}$ & $7(55)^{\mathrm{a}}$ \\
\hline$R_{\mathrm{C}} 85$ & 121 & 88 & 84 & $141^{\mathrm{a}}, 100^{\mathrm{b}}, 140^{\mathrm{c}}$ \\
\hline \multicolumn{5}{|l|}{ Individual River Basins } \\
\hline Ebro & $141(32)$ & $137(56)$ & $43(83)$ & $161^{\mathrm{d}}$ \\
\hline Rhone & $488(22)$ & $459(22)$ & $563(20)$ & $559^{\mathrm{d}}$ \\
\hline Po & $501(25)$ & $356(23)$ & $736(16)$ & $675^{\mathrm{d}}$ \\
\hline Danube & $256(26)$ & $266(16)$ & $252(22)$ & $254^{\mathrm{d}}$ \\
\hline \multicolumn{5}{|l|}{ The Black Sea } \\
\hline$R_{\mathrm{B}}$ & $903(24)$ & $907(16)$ & $884(18)$ & $879^{\mathrm{a}}(12), 875^{\mathrm{e}}, 628^{\mathrm{d}}$ \\
\hline$P_{\mathrm{B}}-E_{\mathrm{B}}$ & $-365(24)$ & $-290(112)$ & $-292(157)$ & $-125^{\mathrm{e}}$ \\
\hline$P_{\mathrm{B}}-E_{\mathrm{B}}+R_{\mathrm{B}}$ & 538 & 617 & 592 & $750^{\mathrm{e}}, 408^{\mathrm{f}}$ \\
\hline$I_{\mathrm{B}}$ & 99 & 114 & 109 & $120^{\mathrm{e}}, 75^{\mathrm{f}}$ \\
\hline \multicolumn{5}{|l|}{ The Mediterranean Sea } \\
\hline$R_{\mathrm{M}}\left(R_{\mathrm{C}} 85+\mathrm{I}_{\mathrm{B}}\right)$ & 220 & 202 & 193 & $196^{\mathrm{g}} 216^{\mathrm{h}} 265^{\mathrm{i}}$ \\
\hline$P_{\mathrm{M}}-E_{\mathrm{M}}$ & $-832(6)$ & $-772(7)$ & $-657(8)$ & $-680^{\mathrm{b}}-603^{\mathrm{b}}-699^{\mathrm{b}},-594^{\mathrm{b}}$ \\
\hline$P_{\mathrm{M}}-E_{\mathrm{M}}+R_{\mathrm{M}}$ & -612 & -571 & -464 & $-494^{\mathrm{b}}-524^{\mathrm{b}}-391^{\mathrm{b}},-570^{\mathrm{b}}$ \\
\hline Gibraltar Strait net flux & & & & $-631^{\mathrm{j}, \mathrm{k}}-505^{1, \mathrm{~m}}-1135^{\mathrm{n}}$ \\
\hline
\end{tabular}

${ }^{\mathrm{a}}$ Ludwig et al. (2009), ${ }^{\mathrm{b}}$ Mariotti and Struglia (2002), ${ }^{\mathrm{c} B o u k t h i r}$ and Barnier (2000), ${ }^{\mathrm{d}}$ Vorosmarty et al. (1998), ${ }^{\mathrm{e}}$ Stanev et al. (2000), ${ }^{\mathrm{f}}$ Lacombe and Tchernia (1972), ${ }^{\mathrm{g}}$ Garcia-Lafuente et al. (2007), ${ }^{\mathrm{h}}$ Bethoux (1979), ${ }^{\mathrm{i}}$ Stanev et al. (2000) and ${ }^{\mathrm{i}}$ Vorosmarty et al. (1998), ${ }^{\mathrm{j}}$ Tixeront (1970), ${ }^{\mathrm{k}}$ Baschek et al. (2001), ${ }^{\mathrm{B}}$ Bryden et al. (1994), ${ }^{\mathrm{m}}$ Candela (2001), ${ }^{\mathrm{n}}$ Tsimplis and Baker (2000), ${ }^{\circ}$ Tomczak and Godfrey (1994). For cases where the observed value was reported as a volume flux, the observed areas given in Table 1 were used to convert the value to mm year ${ }^{-1}$

and the observed precipitation from the CRU dataset. For most of the sub-basins, except those in which there is not much topography such as the Black Sea and the SouthLevantine basins, the HiRes model has the highest runoff ratio of the three models. Although in most cases the HiRes model's runoff ratio is not as high as the observed, one must keep in mind the low elevation station bias in the observed precipitation dataset which would lead to an under-representation of precipitation and thus a higher observed runoff ratio.

Unlike the larger C85 sub-basins, the HiRes model does not always produce the highest runoff estimate in the individual river basins. In fact, in the Rhone and Po basins the LoRes model produces the highest and best runoff estimates (biases are +1 and $+9 \%$, respectively). However, it should be noted that the better runoff estimates by the
Table 7 Modelled and observed runoff ratio values (runoff/precipitation) for the Mediterranean Sea sub-basins

\begin{tabular}{lllll}
\hline & \multicolumn{3}{l}{ Runoff/precipitation } & \\
\cline { 2 - 5 } & HiRes & MedRes & LoRes & Obs \\
\hline Alboran & 0.07 & 0.04 & 0.00 & 0.07 \\
South-Western & 0.03 & 0.01 & 0.00 & 0.13 \\
North-Western & 0.30 & 0.25 & 0.25 & 0.36 \\
Tyrrhenian & 0.12 & 0.07 & 0.00 & 0.27 \\
Adriatic & 0.40 & 0.33 & 0.38 & 0.46 \\
Ionian & 0.17 & 0.07 & 0.08 & 0.29 \\
Central & 0.01 & 0.00 & 0.00 & 0.04 \\
Aegean & 0.19 & 0.14 & 0.16 & 0.26 \\
North-Levantine & 0.22 & 0.11 & 0.15 & 0.23 \\
Black Sea & 0.25 & 0.22 & 0.25 & 0.25 \\
\hline
\end{tabular}


LoRes model found in these basins are due to the large positive precipitation bias found in these regions (Fig. 4) rather than improved physical processes. In the Ebro river basin, the HiRes and MedRes models have runoff biases of -12 and $-15 \%$, respectively, while the LoRes model grossly underestimates runoff by more than $70 \%$. All of the models give similar estimates of runoff from the Danube river basin which is expected given the flatness of the terrain, and are within less than $5 \%$ of the observed value. These river basins are considerably smaller than the C85 sub-basins and therefore a higher resolution model may be necessary to capture the regional land-surface forcings in order to estimate the hydrological components.

Observed values of total freshwater $\left(R_{\mathrm{M}}\right)$ entering the Mediterranean Sea range from 196-265 $\mathrm{mm} \mathrm{year}^{-1}$. The HiRes and MedRes model estimates are both within this range (220 and $202 \mathrm{~mm} \mathrm{year}^{-1}$, respectively), while the LoRes model estimate is slightly lower $\left(193 \mathrm{~mm} \mathrm{year}^{-1}\right)$. Model estimates of $P_{\mathrm{M}}-E_{\mathrm{M}}$ over the Mediterranean Sea are $-832,-772$ and $-657 \mathrm{~mm} \mathrm{year}{ }^{-1}$ for the HiRes, MedRes and LoRes models, respectively. The observed values presented in Table 6 range from -594 to $-699 \mathrm{~mm}$ year $^{-1}$, therefore the LoRes model has the smallest bias. However, the observed estimates of Mariotti and Struglia (2002) and Boukthir and Barnier (2000) use coarse resolution reanalysis data to obtain their estimates which may in fact underestimate evaporation over the Sea. There are other estimates in the literature which are much higher. For example, Castellari et al. (1998) estimated $P_{\mathrm{M}}-E_{\mathrm{M}}$ to be between -620 and $-1,018 \mathrm{~mm}$ year $^{-1}$, while Bethoux and Gentili (1999) estimates range from -832 to $-1,230 \mathrm{~mm}$ year $^{-1}$. Naturally, there is a lot of disagreement in the literature as to the actual value of $P_{\mathrm{M}}-E_{\mathrm{M}}$, therefore it is difficult to judge which model produces the best estimate, however it is worth noting that all model estimates are within the observed range.

The complete estimates of the hydrologic balance $\left(P_{\mathrm{M}}-E_{\mathrm{M}}+R_{\mathrm{M}}\right)$ over the entire Mediterranean basin for the HiRes, MedRes and LoRes models are $-612,-571$ and $-464 \mathrm{~mm}$ year $^{-1}$, respectively. The Mediterranean hydrological budget (including the Black Sea input) can be estimated by two different ways, either from the atmospheric branch or from the oceanic branch of the Mediterranean Sea water cycle. In the first case, one needs to estimate the various terms as we have done using the ARPEGE simulations. In the second case, the net $P_{\mathrm{M}}-E_{\mathrm{M}}$ $+R_{\mathrm{M}}$ flux is computed as the net water transport through the Gibraltar Strait. Over a multi-year period of time, both estimate should agree. However, up-to-now in the literature, the two estimates do not agree, with a higher value coming from the oceanic estimate. Both estimates include their own uncertainties and it is difficult to decide which one is the truth: the atmospheric branch is mainly estimated from non-perfect reanalyses or low resolution satellite datasets in a frame of large interannual variability whereas the oceanic branch is more stable from one year to another but is estimated from few vertical profiles across the Gibraltar Strait and over too short periods of time. In our study, the HiRes and MedRes model estimates of -612 and $-571 \mathrm{~mm}$ year $^{-1}$ lie somewhere in between the upper range of the atmospheric estimates and the lower range of the oceanic estimates. The LoRes model estimate of $-464 \mathrm{~mm}$ year $^{-1}$ is in the lower end of the atmospheric observed estimates. While the HiRes and MedRes models give similar estimates of the total Mediterranean hydrological budget which are both within the range of uncertainty, it is important to point out that the HiRes model's estimate is more physically correct because its runoff estimate from the Mediterranean $\left(R_{\mathrm{C}} 85\right)$ is within the range of the observed values while the MedRes model estimate is below the range.

In order to evaluate how well the models reproduce the interannual variability in runoff and $P-E$ over the sea we compare the models' coefficient of variation (CV) to the observed. The CV is calculated by dividing the standard deviation in average annual runoff by the mean. It is difficult to draw any conclusions as to how well the models are able to reproduce the interannual variability in runoff from the ten Mediterranean sub-basin by comparing the $\mathrm{CV}$ given in parenthesis in Table 6. In the European subbasins (NWE, ADR, TYR, ION, AEG, and NLE), the HiRes model produces a value closest to that of the observed in the majority of the cases. The one exception is in the Adriatic basin, however the differences between the models are not very large. None of the models reproduce the interannual variability well in the other basins which are quite dry (ALB, SWE, CEN, SLE). Over the Black Sea basin, the $\mathrm{CV}$ produced by the MedRes and LoRes models, 16 and 18 , respectively, are closer to the observed value of 12 , while the HiRes produces too much variability having a $\mathrm{CV}$ of twice as much as the observed. This is indicative of the fact that the Black Sea basin is largely flat, thus resolution does not produce significant improvements.

\subsection{The Caspian Sea region}

For the Caspian Sea basin we examine runoff from the Volga, Kura and Ural river basins which together contribute over $90 \%$ of the freshwater runoff into the Caspian Sea. The Caspian Sea is a closed sea with no outlet to the Ocean, thus $P-E$ should be equal to total runoff over the long-term. However, the Caspian Sea basin is especially sensitive to multi-decadal climate variability which has led to long periods of the Sea either rising or falling rapidly (Rodionov 1994). As such, it is difficult to obtain a true climatology of the individual components of the 
hydrological balance, and this should be kept in mind when interpreting the results. The observations were calculated for the period 1960-1999, part of which time after the late seventies, the hydrologic budget was positive due to increased precipitation in the northern basin and higher evaporation over the Sea (Elguindi and Giorgi 2005). One should also keep in mind that we are evaluating runoff from only three river basins, and although they account for over $90 \%$ of the total runoff into the Sea, there is still another approximately $10 \%$ that we do not account for.

Resolution has a large impact on estimated runoff in the Volga basin. The HiRes model has the smallest bias $(-10 \%)$ while the MedRes and LoRes models largely underestimate runoff by -48 and $-60 \%$, respectively. Contrarily, in the Kura basin, runoff estimates decrease as model resolution increases, however all of the models overestimate runoff by between $96 \%$ in the HiRes model to over $240 \%$ in the LoRes model. This is a result of the large overestimation of precipiation in the MedRes and LoRes models over the Kura basin. The HiRes model produces the best runoff estimate in the Ural basin as well, with a bias of $-50 \%$ compared to -83 and $-100.0 \%$ in the MedRes and LoRes models, respectively. Overall, the HiRes model produces the best estimate total runoff $\left(R_{\mathrm{C}}\right)$, having a bias of $<5 \%$, while the MedRes and LoRes models underestimate it by -35 and $-42 \%$.

In comparing the models' runoff ratio (Table 8) we find that the HiRes model has the highest ratios, which are closest to the observed, over the Volga and Ural basins. However, over the Kura basin we find the opposite in that the LoRes model has the highest ratio (0.35), and all models overestimate this ratio in comparison to the observed value of 0.16 . The fact that the LoRes and MedRes models have such high runoff ratios is a reflection of how poorly they perform over this region, namely their overestimation of precipitation.

$P_{\mathrm{C}}-E_{\mathrm{C}}$ is overestimated by about $10-15 \%$ by the HiRes model and $<5 \%$ by the MedRes model, while the LoRes model underestimates $P_{\mathrm{C}}-E_{\mathrm{C}}$ by $38 \%$. In comparing the total $\left(P_{\mathrm{C}}-E_{\mathrm{C}}+R_{\mathrm{C}}\right)$ budget, the HiRes, MedRes and LoRes models produce estimates of -126 , -231 and $-25 \mathrm{~mm}$ year $^{-1}$, respectively. The observed hydrologic balance is close to zero, -16 or $1 \mathrm{~mm}_{\text {year }}{ }^{-1}$,

Table 8 Modelled and observed runoff ratio values (runoff/precipitation) for the Caspian Sea basins

\begin{tabular}{lllll}
\hline & \multicolumn{4}{l}{ Runoff/precipitation } \\
\cline { 2 - 5 } & HiRes & MedRes & LoRes & Obs \\
\hline Volga & 0.23 & 0.15 & 0.14 & 0.23 \\
Kura & 0.24 & 0.25 & 0.35 & 0.16 \\
Ural & 0.04 & 0.02 & 0.00 & 0.08 \\
\hline
\end{tabular}

depending on how evaporation over the Sea is calculated. Although it appears that the LoRes model provides the best estimate this is not necessarily for good physical reasons because the model significantly underestimates both runoff and $P_{\mathrm{C}}-E_{\mathrm{C}}$. Rather the HiRes model again produces the best estimate of $R_{\mathrm{C}}$ in comparison to the observations. Also, both the HiRes and MedRes models produce reasonable estimates of $P_{\mathrm{C}}-E_{\mathrm{C}}$, while the LoRes model significantly underestimates it.

The coefficient of variation in annual runoff in the river basins of the Caspian Sea are noted in parenthesis in Table 9. The HiRes, MedRes and LoRes models all produce too much variability in the Volga basin (40, 35, and $57 \%$ ) compared to the observed CV of $19 \%$. However, the Volga rive is highly regulated so one cannot expect to simulate the same variability as observed. In the Kura basin where there is mountainous terrain, the HiRes and MedRes reproduce the interannual variability well, while the LoRes model produces too much variability. In the Ural basin, all of the models significantly overestimate the variability in runoff.

\section{Future changes}

Several recent global climate change studies have reported significant changes in the hydrological cycle characteristics of the Mediterranean, Black and Caspian Sea basins (Giorgi 2006; Sheffield and Wood 2008; Mariotti et al. 2008; Somot et al. 2006; Elguindi and Giorgi 2007). Based on the IPCC-AR4 GCMs, Giorgi (2006) identified the Mediterranean region as a climate change "hot-spot" in which decreased precipitation and increased temperature would lead to an overall drying of the region. Using multimodel projections from the World Climate Research Program Coupled Model Intercomparison Project Phase 3 (CMIP3), Mariotti et al. (2008) further analyzed future changes in the Mediterranean hydrologic cycle characteristics. Based on the multi-model ensemble mean, they report a $20 \%$ reduction in total runoff and a $24 \%$ decrease in $P-E$ over the Sea by the end of the century. Recently, Sanchez-Gomez et al. (2009a) used the 25-km RCM simulations of the European project ENSEMBLES to estimate the water budget of the Mediterranean Sea. Their ensemble average predicts a $-10 \%$ (range is from -42 to $+21 \%$ ) reduction in runoff and a $15-35 \%$ decrease in $P-E$ for the 2040s (SRES-A1B scenario). These last results are qualitatively in agreement with Mariotti et al. (2008) but can not be properly compared to understand the role of the spatial resolution. Indeed the scenario, the time period and the model physics are not identical. In contrary, our study allows a clean evaluation of the resolution impact as it is the only modified factor in our experiments. 
Table 9 Modelled and observed average runoff values in the Caspian Sea basin in $\mathrm{mm}_{\mathrm{year}}{ }^{-1}$

\begin{tabular}{lllll}
\hline & HiRes & MedRes & LoRes & Observations \\
\hline Volga & $155(40)$ & $90(35)$ & $68(57)$ & $172(19)_{1}$ \\
Kura & $162(19)$ & $226(21)$ & $283(29)$ & $83(18)_{1}$ \\
Ural & $18(122)$ & $6(180)$ & 0 & $36(58)_{1}$ \\
$R_{\mathrm{C}}$ & 661 & 450 & 402 & $689_{1}$ \\
$P_{\mathrm{C}}-E_{\mathrm{C}}$ & $-786.9(10)$ & $-680.8(11)$ & $-426.5(15)$ & $-704.9_{1}-687.5_{2}$ \\
$P_{\mathrm{C}}-E_{\mathrm{C}}+R_{\mathrm{C}}$ & -126 & -231 & -25 & $-16_{1} 1_{2}$ \\
\hline
\end{tabular}

The coefficient of variation is given in parenthesis. Georgievsky et al. (2003) 1,2

Future climate change studies have been performed over the Caspian region as well. Using a regional climate model (RCM) nested in time-slice GCM simulations under the Special Report Emissions Scenario A2 for the period 20712100 Elguindi and Giorgi (2007) found substantial changes in the hydrological balance of the Caspian Sea basin. Namely, large increases in temperature and evaporation over the basin offset the increases in wintertime precipitation leading to a deficit in the hydrological budget towards the end of the century. Similarly, Arpe and Leroy (2007) performed future climate simulations over the Caspian Sea basin using the Max Planck Institute for Meteorology GCM, although their results were less conclusive.

In the previous section we showed that increasing the model resolution produces the best estimates of the hydrological budget components over the Mediterranean and Caspian Sea basins, particularly over mountainous regions. In this section, we examine whether the future evolution of the hydrological budget is dependent on model resolution, or whether all three models produce similar future climate changes in terms of spatial pattern and intensity. Specifically, we compare temperature, precipitation and evaporation climatological fields from the future simulations (2046-2070) to the present-day simulations (1979-2002) produced by the HiRes, MedRes and LoRes models. An analysis of the impact of future climate changes on the hydrological balance of the Mediterranean, Black and Caspian Sea basins is then presented.

\subsection{Changes in temperature, precipitation and evapotranspiration}

\subsubsection{The Mediterranean Sea region}

As expected, temperatures warmed all across the Mediterranean domain in the future simulations (Fig. 7). The greatest warming occurred during the summer season (JJA) where temperatures increased by more than $3-4^{\circ} \mathrm{C}$ in parts of the domain, namely central Spain and in the region around the Black Sea in Turkey, Ukraine and Russia.
Somewhat surprisingly, the largest response is in the LoRes model where the warming is most severe and spatially extensive, while the MedRes model had the most modest response. During the winter season (DJF), temperatures warmed up to between 2 and $3^{\circ} \mathrm{C}$ across the domain, with the strongest warming occurring in North Africa.

The largest changes in evaporation occur over the Mediterranean and Black seas (Fig. 8) where evaporation increases by over $1 \mathrm{~mm} \mathrm{day}^{-1}$ in some areas. The largest increases are in the HiRes and MedRes models, both in winter and summer. While there are increases over the sea in the LoRes model, it is less extreme than in the other two models during the winter and almost negligible during the summer. Evaporation decreases occur over parts of Spain, France and areas around the Black Sea.

Noticeable changes in precipitation are found among all three models (Fig. 9). During the winter, precipitation increases over some parts of the basin and decreases over other parts. While the region of increased and decreased precipitation vary among the models, these differences are likely fluctuations around an unchanged situation rather than an effective signal due to resolution. During the summer, precipitation decreases significantly over much of the european part of the basin. The exception is over the Alps in northern Italy where significant increases in precipitation occur in the HiRes model.

\subsubsection{The Caspian Sea region}

In the Caspian region, there is an up to $4^{\circ} \mathrm{C}$ warming over the basin during the summer (Fig. 10). The warming is greater in the northern Caspian basin in the HiRes model than in the MedRes or LoRes models. During the winter, there is also significant warming of up to between 3 and $4^{\circ} \mathrm{C}$ in parts. The warming is greater in the north and decreases gradually towards the south due to snow-albedo feedback. During the winter, changes in evaporation are evident mainly over the Caspian Sea where significant increases (up to $1 \mathrm{~mm}^{\text {day }}{ }^{-1}$ ) have occurred in all of the models (Fig. 11). Contrarily, during the summer there are decreases in evaporation over the Sea. During the summer, 
Fig. 7 Difference plots (future minus present-day) between present-day and future temperature $\left({ }^{\circ} \mathrm{C}\right)$ climatology over the Mediterranean and Black Sea basins for the HiRes, MedRes and LoRes models during winter $(D J F)$ and summer $(J J A)$ seasons
DJF (HiRes)

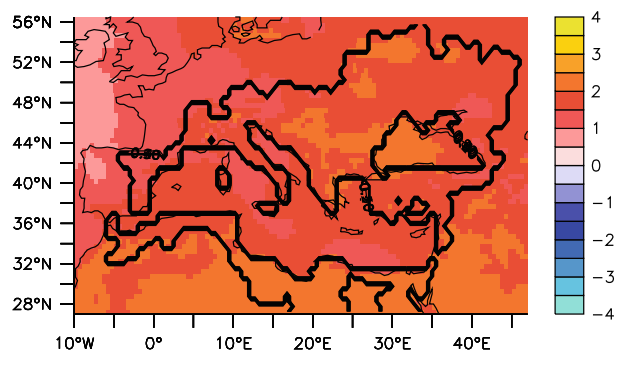

DJF (MedRes)

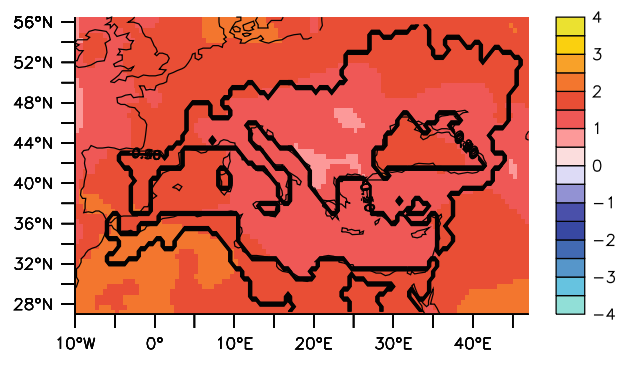

DJF (LoRes)

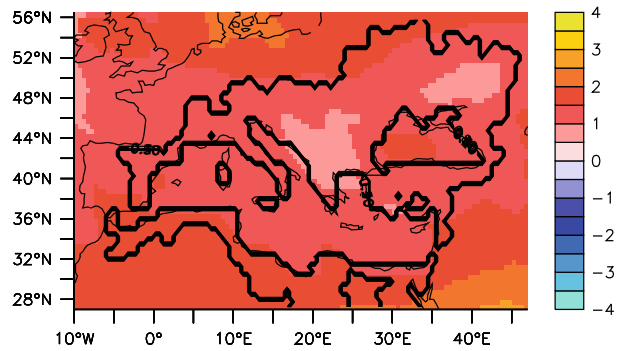

JJA (HiRes)

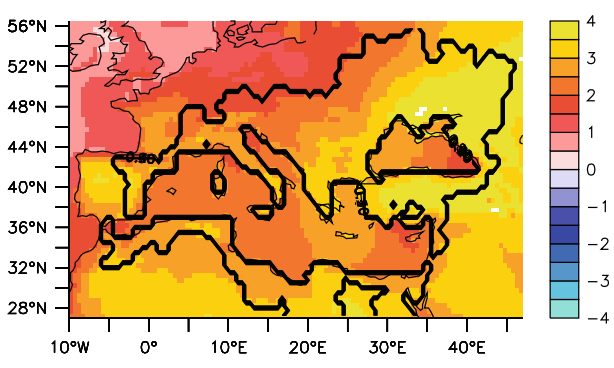

JJA (MedRes)

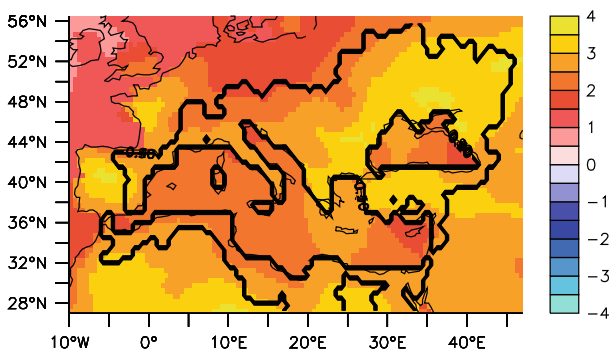

JJA (LoRes)

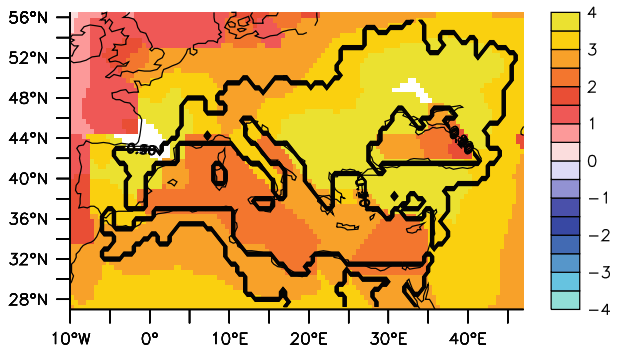

precipitation decreases over much of the Caspian basin (Fig. 12). The changes in winter precipitation are much less pronounced, with only a few areas of increases occuring in mainly the southern part of the basin.

\subsection{Impact on the hydrologic cycle}

\subsubsection{The Mediterranean Sea region}

Percent changes in the models' calculated runoff due to projected climate change for the various sub-basins are presented in Table 10. The mean fluxes between the HiRes model and the lower resolution models are all statistically different (5\% significance level) except for runoff from the Black Sea basin $\left(R_{\mathrm{B}}\right)$. Mean fluxes between the MedRes and LoRes models are statistically different except for runoff from the ADR, NLE and SLE basins, and $P_{\mathrm{B}}-E_{\mathrm{B}}$ over the Black Sea.

Runoff decreases in all of the sub-basins, and in the majority of cases the decreases are slightly greater in the MedRes model than in the HiRes model but significantly greater in the LoRes model than either the HiRes or MedRes models. Percent changes are greatest in the Alboran, South-Western and Ebro basins $(-42,63$ and $-44 \%$, respectively), however, there is comparatively less presentday runoff in these basins so the absolute changes in runoff are not large. The South-Levantine sub-basin is the only area in which runoff actually increases by $10 \%$ in the HiRes. In terms of total runoff $\left(R_{\mathrm{C}} 85\right)$, the HiRes model shows an $-17 \%$ decrease, while the MedRes shows a slightly higher $-20 \%$ decrease and the LoRes model show the greatest decrease of $-33 \%$.

Interestingly, runoff from the Black Sea basin has nearly no change in the HiRes and MedRes models. It is not surprising that the mean runoff is not statistically different between the two models in this region since the terrain is mostly flat. Consistent with the other changes in runoff, the LoRes model shows the largest decrease of $-30 \% . P_{\mathrm{B}}-E_{\mathrm{B}}$ decreases by approximately 30, 46 and 29\% in the HiRes, MedRes and LoRes models, respectively. Due to the significantly reduced runoff and increased evaporation over the sea, the Black Sea basin contributes $47 \%$ less total 
Fig. 8 Difference plots (future minus present-day) between present-day and future evapotranspiration $\left(\mathrm{mm}\right.$ day $\left.^{-1}\right)$ climatology over the Mediterranean and Black Sea basins for the HiRes, MedRes and LoRes models during winter (i)s and summer (JJA) seasons
DJF (HiRes)

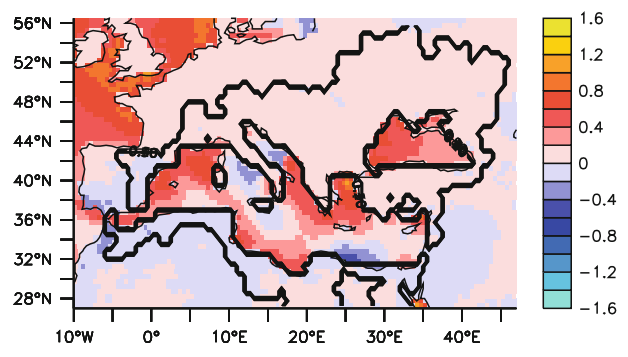

DJF (MedRes)

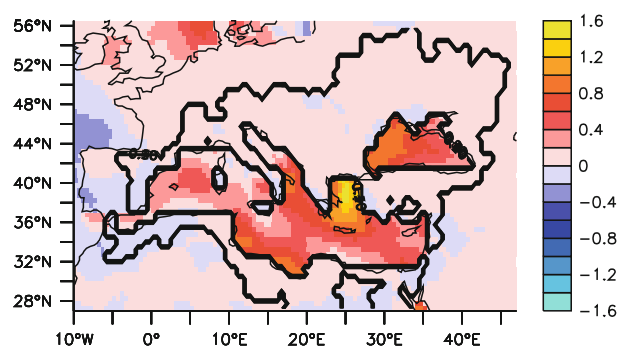

DJF (LoRes)

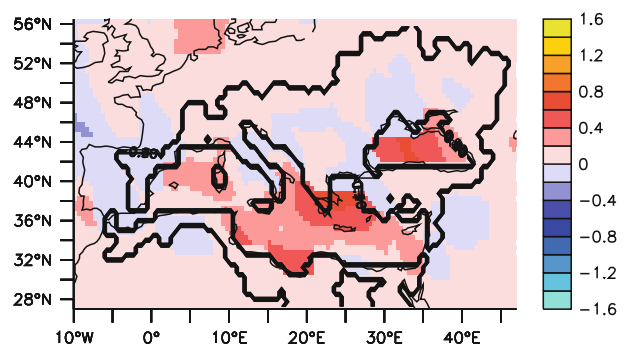

JJA (HiRes)

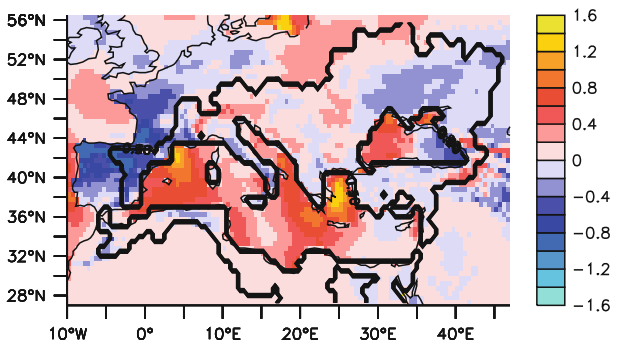

JJA (MedRes)

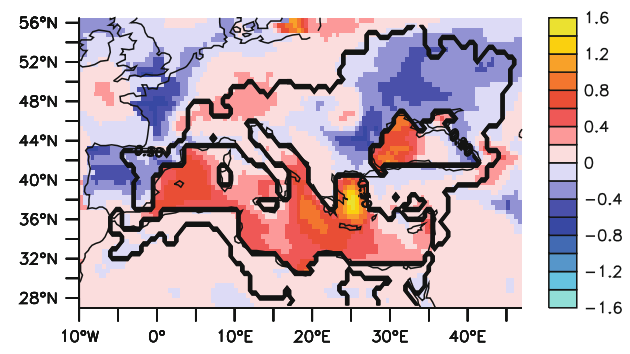

JJA (LoRes)

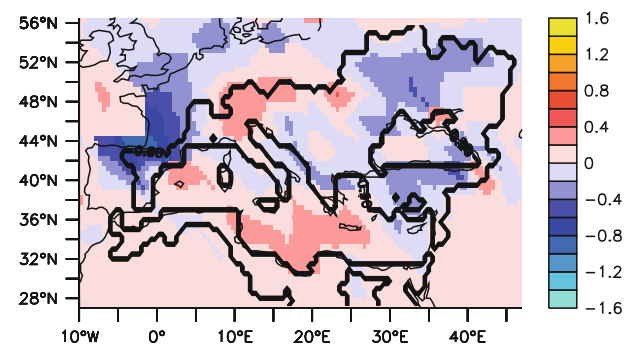

freshwater input to the Mediterranean Sea in the LoRes model. Contributions in the HiRes and MedRes models are also reduced by 19 and 30\%, respectively.

The runoff ratios for the sub-basins are presented in Table 11. Universally, the ratio decreases, indicative of the fact that the efficiency of the hydrological system to produce runoff from a given amount of precipitation decreases in a warmer climate, namely as a result of the decrease in precipitation and increase in evapotranspiration. The decrease in the sub-basins' runoff ratio is an indication of the reduction in water resources that will be available to the local communities.

In terms of the impact of future climate changes on the hydrologic budget of the Mediterranean Sea, the HiRes model has an approximately $18 \%$ decrease in total freshwater runoff and $22 \%$ decrease in $P_{\mathrm{M}}-E_{\mathrm{M}}$, resulting in $36 \%$ decrease in the total Mediterranean Sea basin budget. Based on the CMIP3 multi-model ensemble, Mariotti et al. (2008) report a 19.6 and $23.4 \%$ reduction in total runoff into the Mediterranean Sea during the wet (OctoberMarch) and dry (April-September) seasons by the end of the century. They report $P_{\mathrm{M}}-E_{\mathrm{M}}$ to decrease by 29.6 and $19.2 \%$ during the wet and dry seasons, respectively. Because these projections are for the end of the century, they are not directly comparable with our mid-century estimates, however, Mariotti et al. (2008) shows that the projected trends begin during the early part of the century and continue at a steady rate throughout the century, thus we are able to infer something about mid-century changes. While the HiRes model shows an $18 \%$ mid-century reduction in total runoff which is slightly less than the end of the century reduction shown by the CMIP3 ensemble, both the MedRes and LoRes models show reductions which are greater, 26 and $48 \%$, respectively. Likewise, the HiRes model's estimate of decreased $P_{\mathrm{M}}-E_{\mathrm{M}},-22 \%$, is closer to the CMIP3 model ensemble mean than the -18 and $-15 \%$ estimates of the MedRes and LoRes models, respectively.

All of the models show a substantial reduction in the total Mediterranean hydrological budget, ranging from 33 to $41 \%$. The reduction in amount of total freshwater reaching the Sea is significantly greater in the MedRes and LoRes models $(-26$ and $-48 \%)$ than in the HiRes model 
Fig. 9 Difference plots (future minus present-day) between present-day and future precipitation $\left(\mathrm{mm} \mathrm{day}^{-1}\right)$ climatology over the Mediterranean and Black Sea basins for the HiRes, MedRes and LoRes models during winter $(D J F)$ and summer $(J J A)$ seasons
DJF (HiRes)

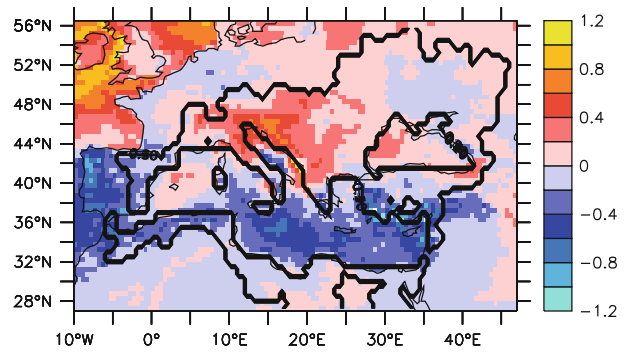

DJF (MedRes)

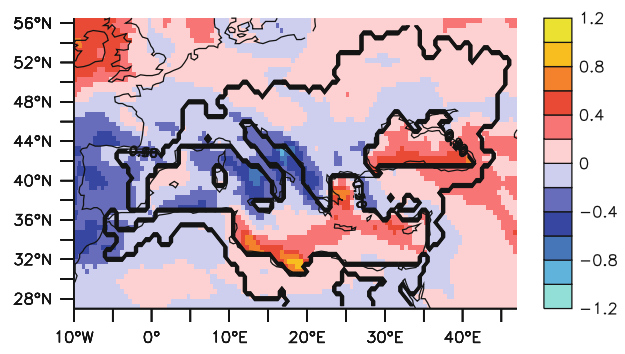

DJF (LoRes)

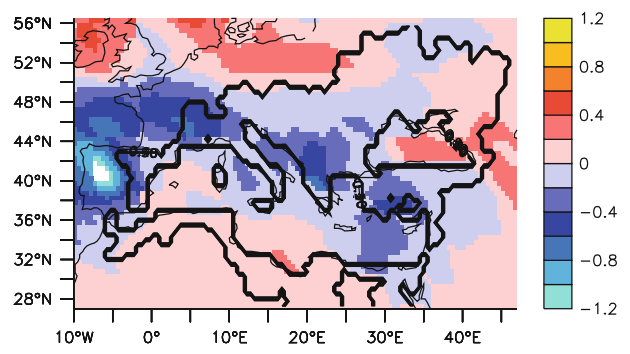

JJA (HiRes)

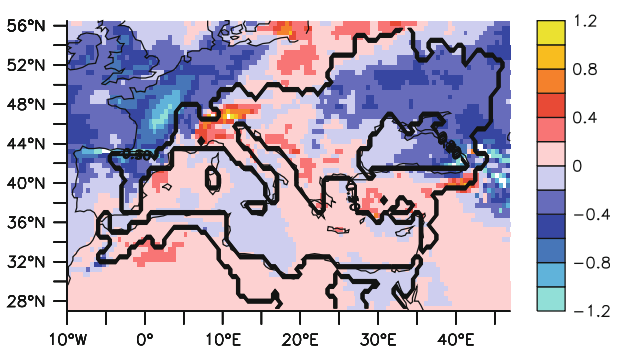

JJA (MedRes)

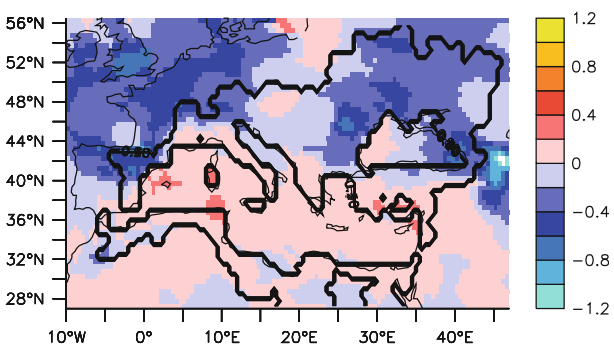

JJA (LoRes)

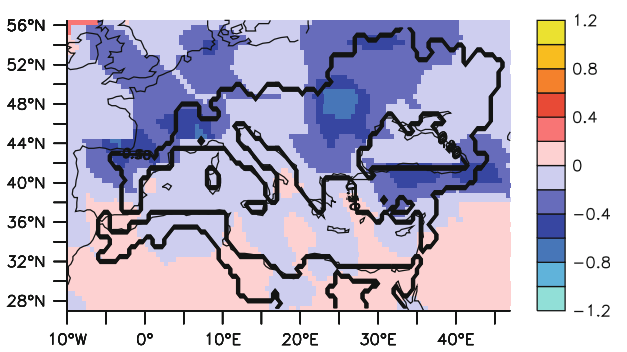

$(-18 \%)$. This is largely due to the more increased warming with decreased resolution found in the models. This is to be expected as differences in the present-day climate state among the models can lead to differences in how the future climate evolves. For example, differences in soil water content will impact summer temperatures, evapotranspiration and even precipitation. On a global scale, resolution can impact weather regimes over Europe due to changes in the tropics-extratropics teleconnections that can be affected by spatial resolution through the representation of the tropical convection. Above all, resolution has a large impact on local forcings, namely orography, which can lead to different future climate responses. A notable example is increased temperatures in mountainous regions which may significantly reduce the snow amount in lower resolution models where topography is not well represented, thus enhancing the warming found in these regions. While it is difficult to prove beyond a doubt, the fact that the HiRes model's mean future climate fluxes (Table 10) are indeed statistically different from the lower resolution models and that the HiRes present-day fluxes are in better agreement with the observations strongly suggests that the
HiRes projected hydrological budget change is more accurate.

The reduction in the total Mediterranean hydrological budget predicted by the models not only indicates a potential depletion in water resources for region's communities, but the decrease $P_{\mathrm{M}}-E_{\mathrm{M}}$ would lead to increased salinity in the seawater which could lead to changes in the MTHC. The MTHC is driven by both the net surface heat loss and the net surface water loss. In a warming climate, the heat loss would decrease leading to an increase in SST and a lightening of the surface water masses. However, an opposite salinity effect (underlined by our study) could counteract this warming in terms of water density, thus affecting the strength of MTHC. Some studies have shown that the increase in SSTs has a stronger influence than the increase in salinity, resulting in a weakening of the MTHC (Thorpe and Bigg 2000; Somot et al. 2006). If the models used in our study had been coupled to an ocean model, the salinity increase would have been simulated and it would have been interesting to see what kind of role resolution played on balancing the effects of increased salinity and decreased heat loss. 
Fig. 10 Difference plots (future minus present-day) between present-day and future temperature $\left({ }^{\circ} \mathrm{C}\right)$ climatology over the Caspian Sea basin for the HiRes, MedRes and LoRes models during winter $(D J F)$ and summer $(J J A)$ seasons

\subsubsection{The Caspian Sea region}

Percent changes in the models' runoff over the Caspian basin due to projected climate change are presented in Table 12. The models are not consistent in their projected changes of the individual hydrological budget components. For example, runoff from the Volga basin is projected to decrease in the HiRes and LoRes models, but increase in the MedRes model. In the Kura basin, the HiRes model projects a $5 \%$ decrease in runoff, while the MedRes model projects a $4 \%$ increase and the LoRes model projects no change at all. Projected runoff changes in the Ural basin are larger but there is still no agreement among the models. The HiRes model projects a 38\% increase and the MedRes model projects a $20 \%$ increase. $P_{\mathrm{C}}-E_{\mathrm{C}}$ is projected to decrease by the HiRes and MedRes models by 7 and $6 \%$, respectively, and increase by $4 \%$ in the LoRes model. Despite the lack of agreement among the models in the projected changes of the individual hydrological budget components, all of them project decreases in the total overall budget $(60,6$ and $28 \%$ in the HiRes, MedRes and LoRes models, respectively).
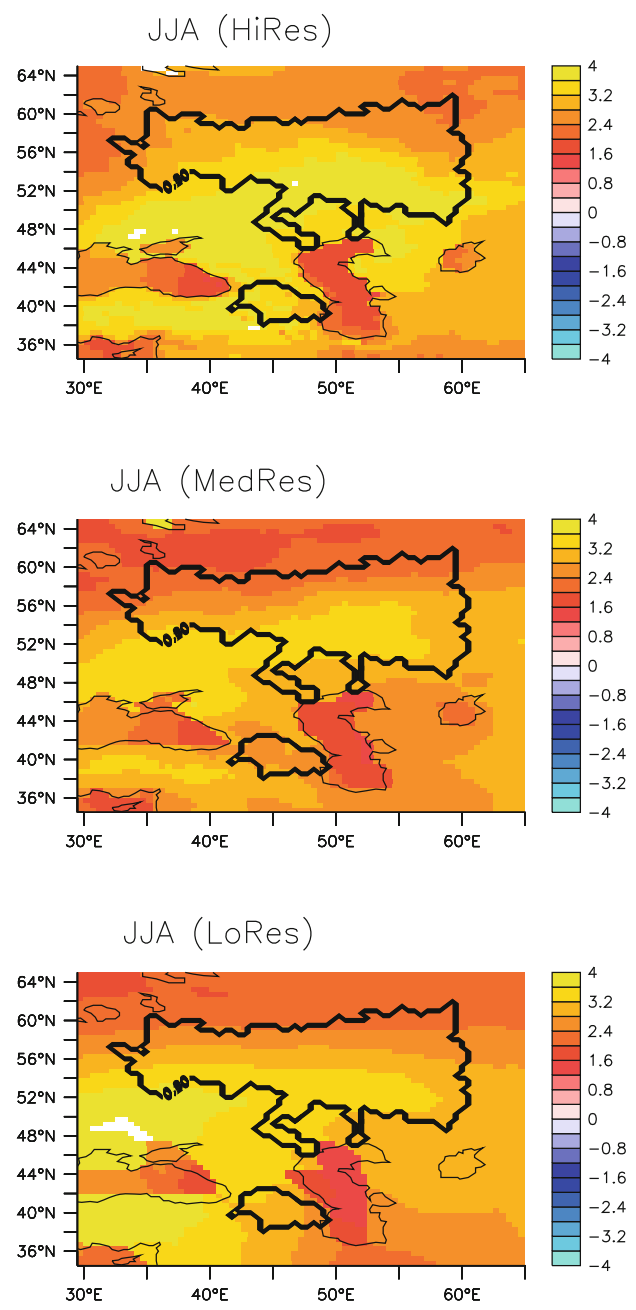

\section{Discussion and conclusions}

In this study, we have examined how well the ARPEGECLIMATE V4 global model is able to reproduce the hydrological balance of the Mediterranean, Black and Caspian Seas. Three simulations were performed using ARPEGE-CLIMATE V4 which were identical except for the horizontal resolution in order to isolate and study the effects of resolution on simulating the hydrological components. Model calculated values of average present-day runoff and $P-E$ were compared to a variety of data sources. In general, the models underestimate runoff in most of the basins. Total runoff into the Mediterranean Sea, excluding the Black Sea basin, estimated by the HiRes model is within the range of observations, while the MedRes and LoRes models underestimate it by at least -12 and $-16 \%$ when compared to the lower limit of the observations. As expected, resolution did not have much of an effect on runoff estimates from the Black Sea basin where the terrain is mostly flat. Depending on which data source is considered, the models overestimated runoff by between less than 5 and up to $25 \%$. In the Caspian Sea 
Fig. 11 Difference plots (future minus present-day) between present-day and future evapotranspiration $\left(\mathrm{mm} \mathrm{day}^{-1}\right)$ climatology over the Caspian Sea basin for the HiRes, MedRes and LoRes models during winter $(D J F)$ and summer $(J J A)$ seasons
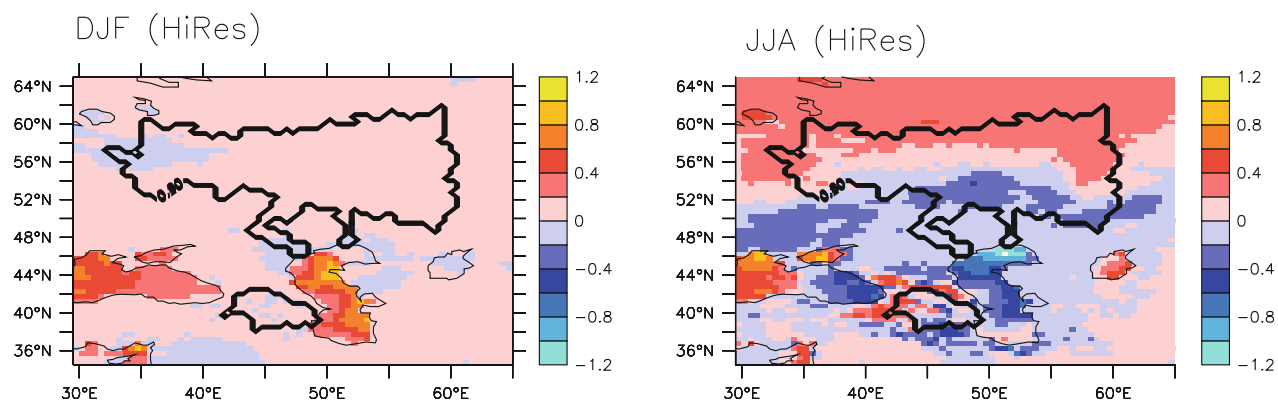

DJF (MedRes)

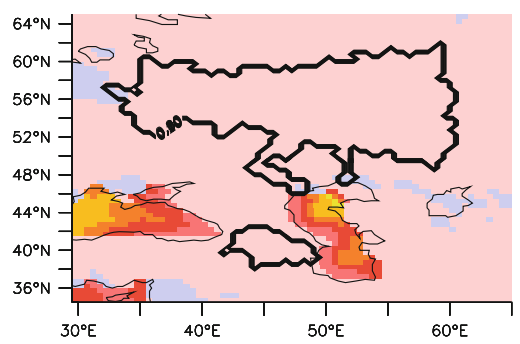

DJF (LoRes)

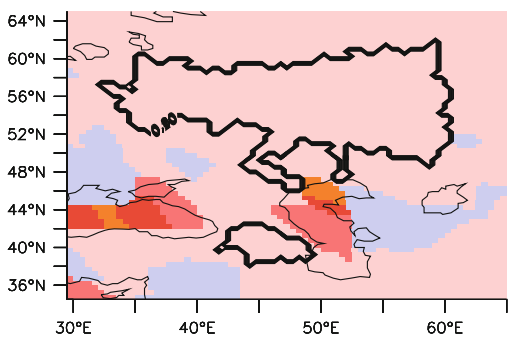

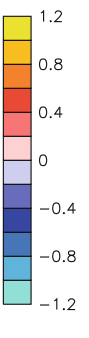

JJA (MedRes)

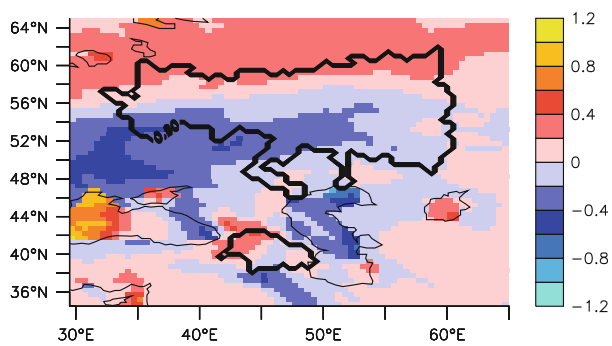

JJA (LoRes)

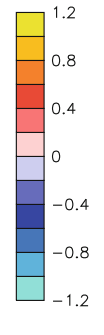

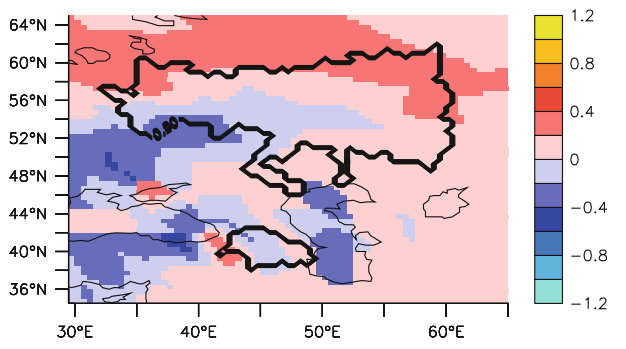

basin, the HiRes model overestimated runoff by only $5 \%$ while the MedRes and LoRes models underestimated runoff by -35 and $-42 \%$, respectively. Overall, we found that the HiRes model improved the runoff estimates based not only on the lower biases but on physical reasons as well. For example, in some cases such as in the Po River the LoRes model produced a better runoff estimate due to a high precipiation bias in the region.

$P_{\mathrm{B}}-E_{\mathrm{B}}$ is largely overestimated by all of the models (by at least $100 \%$ ) indicating that it is not at all represented well by the model. Over the Mediterranean Sea $P_{\mathrm{M}}-E_{\mathrm{M}}$ is better represented and the model biases are all within the observed range of uncertainty. Over the Caspian Sea, the HiRes model overestimates $P_{\mathrm{C}}-E_{\mathrm{C}}$ by between 10 and $15 \%$ while the MedRes model overestimates it by less than $5 \%$. Contrarily, the LoRes model underestimates $P_{\mathrm{C}}-E_{\mathrm{C}}$ by almost $40 \%$.

Observed estimates of the Mediterranean hydrological budget ( $P_{\mathrm{M}}-E_{\mathrm{M}}+R_{\mathrm{M}}$ ) range from -391 to $1,135 \mathrm{~mm}$ year $^{-1}$, indicating a net loss. This large uncertainty range comes from a disagreement between the atmospheric estimate that is lower and the indirect Gibraltar net transport estimate that is larger. This inconsistency has not been solved in the literature up-to-now and constitutes one of the scientific objectives of the forthcoming HyMex project (http://www.cnrm.meteo.fr/hymex/). The HiRes model produces an estimate which is in between the atmospheric and oceanic observed estimates ( $-612 \mathrm{~mm}_{\text {year }}{ }^{-1}$ ), while the MedRes and LoRes models produce estimates which are at the upper and lower end of the atmospheric estimates, -571 and -464 , respectively. Although the HiRes and MedRes models produce similar estimates which are both with the range of uncertainty, we consider the HiRes model to be better because the individual hydrological components, namely runoff and $P-E$, estimated by the HiRes model are closer to observed estimates than those of the MedRes model. For the Caspian Sea, total hydrological balance over the long-term should be near zero. Although the LoRes model produced an average hydrological balance nearest to zero $\left(-25 \mathrm{~mm} \mathrm{year}^{-1}\right)$, it had the largest biases for runoff and $P-E$ over the sea. Thus despite the fact that the HiRes model produces a more negative total hydrologic budget over the Caspian basin $(-126 \mathrm{~mm}$ year $^{-1}$ ), it does a better job in simulating the hydrological 
Fig. 12 Difference plots (future minus present-day) between present-day and future precipitation $\left(\mathrm{mm} \mathrm{day}^{-1}\right)$ climatology over the Caspian basin for the HiRes, MedRes and LoRes models during winter $(D J F)$ and summer $(J J A)$ seasons
DJF (HiRes)

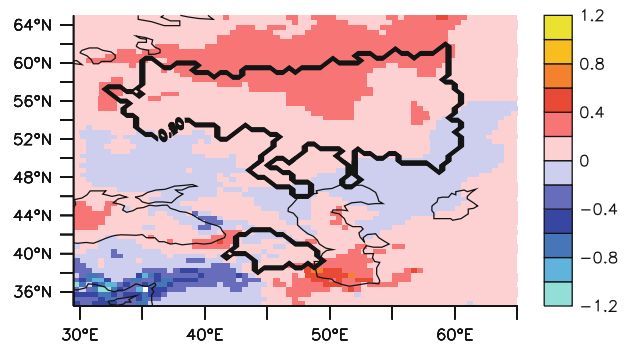

DJF (MedRes)

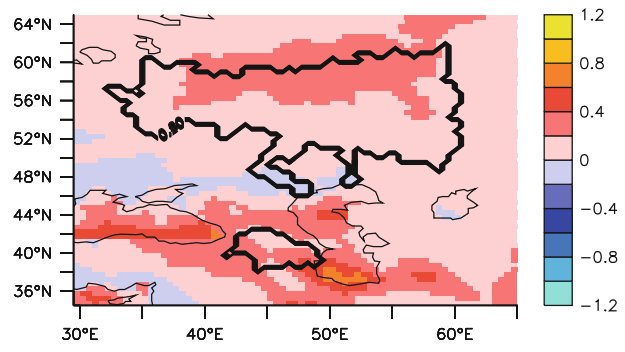

DJF (LoRes)

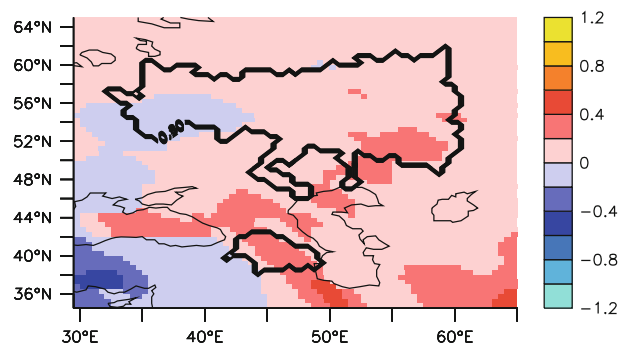

JJA (HiRes)

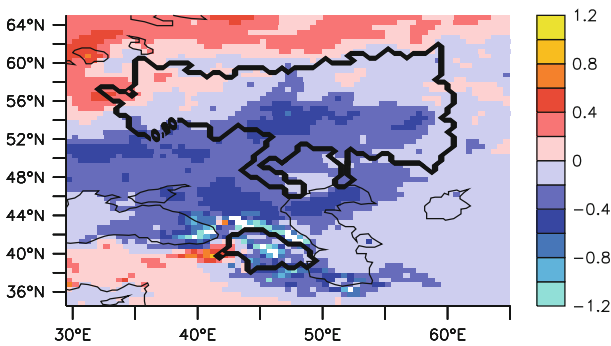

JJA (MedRes)

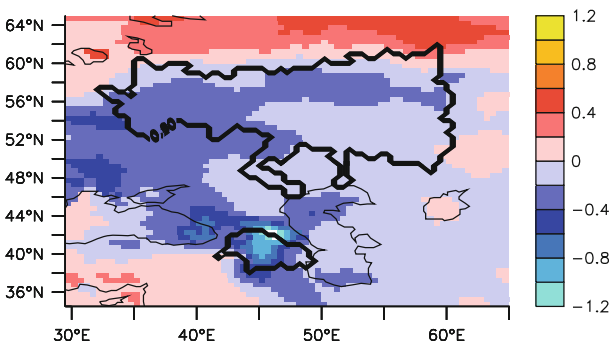

JJA (LoRes)

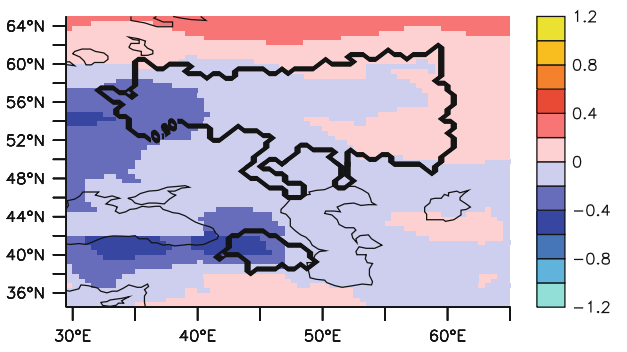

processes which is represented in its better estimates of the individual hydrological components, especially runoff.

In this study, we also examined the impact of horizontal resolution on future climate change simulations. Specifically, we addressed the question of whether or not resolution would change the outcome of the impact climate change would have on the hydrological basins. Output from three future climate change simulations performed with the HiRes, MedRes and LoRes models were compared to the corresponding present-day simulations. In the Mediterranean region, all three models showed similar spatial patterns of warming due to climate change, however, the degree of warming varied. The LoRes model produced the most intense warming, while the MedRes model produced the least. Despite future climate changes in precipitation not being spatially consistent among the models, the response in runoff was generally consistent. Runoff decreased in almost all of the basins and in all of the models, although the percentage of decrease varied. In general, the HiRes model had the smallest decreases in runoff (although still significant) while the MedRes model had slightly larger decreases and the LoRes model had much larger decreases. This was true even in the Black Sea basin where the terrain is largely flat and we would not expect resolution to have a large impact. The effect of resolution on the impact of climate change on runoff in the Caspian sub-basins is more ambiguous, however, when runoff from the entire basin is considered the same pattern emerges with the HiRes and MedRes models having more moderate decreases than the LoRes model.

All of the models show decreases in $P-E$ over the Mediterranean, Black and Caspian seas except for the LoRes model over the Caspain Sea which estimates a slight increase of about $4 \%$. The MedRes model estimates the largest decrease in $P-E$ over the Black Sea, while the HiRes estimates the largest decrease over the Mediterranean and Caspian Seas. When changes in the total hydrological budget over the Mediterranean, Black and Caspian Sea basins are considered all models predict significant decreases, however, the percentage of decrease varies considerably among the models. 
Table 10 Percent change in average runoff values (coefficient of variation) in the Mediterranean Sea basin

\begin{tabular}{|c|c|c|c|}
\hline & HiRes & MedRes & LoRes \\
\hline \multicolumn{4}{|l|}{ DL02 Basins } \\
\hline Alboran & $-42(56)$ & $-49(-21)$ & $* * *$ \\
\hline South-Western & $-63(-6)$ & $-29(2)$ & $* * *$ \\
\hline North-Western & $-22(26)$ & $-27(30)$ & $-37(71)$ \\
\hline Tyrrhenian & $-18(12)$ & $-26(13)$ & $* * *$ \\
\hline Adriatic & $-11(5)$ & $-16_{\mathrm{ML}}(72)$ & $-28_{\mathrm{ML}}(9)$ \\
\hline Ionian & $-34(12)$ & $-41(-3)$ & $-69(58)$ \\
\hline Central & $-18(149)$ & $* * *$ & $* * *$ \\
\hline Aegean & $-22(4)$ & $-22(7)$ & $-53(37)$ \\
\hline North-Levantine & $-32(100)$ & $-24_{\mathrm{ML}}(14)$ & $-61_{\mathrm{ML}}(212)$ \\
\hline South-Levantine & $10(43)$ & $6_{\mathrm{ML}}(8)$ & $-10_{\mathrm{ML}}(7)$ \\
\hline$R_{\mathrm{C}} 85$ & -17 & -20 & -33 \\
\hline \multicolumn{4}{|c|}{ Individual River Basins } \\
\hline Ebro & $-44(31)$ & $-63(7)$ & $-74(12)$ \\
\hline Rhone & $-18(27)$ & $-18(32)$ & $-31(100)$ \\
\hline Po & $-17(12)$ & $-15(48)$ & $-23(56)$ \\
\hline Danube & $-1(-23)$ & $-10(81.3)$ & $-36(22.7)$ \\
\hline \multicolumn{4}{|l|}{ The Black Sea } \\
\hline$R_{\mathrm{B}}$ & $0_{\mathrm{HM}}(-16)$ & $-7_{\mathrm{HM}}(81)$ & $-30(33)$ \\
\hline$P_{\mathrm{B}}-E_{\mathrm{B}}$ & $-30(-33)$ & $-46_{\mathrm{ML}}(-82)$ & $-29_{\mathrm{ML}}(-87)$ \\
\hline$P_{\mathrm{B}}-E_{\mathrm{B}}+R_{\mathrm{B}}$ & -19 & -30 & -47 \\
\hline \multicolumn{4}{|c|}{ The Mediterranean Sea } \\
\hline$R_{\mathrm{M}}$ & -18 & -26 & -48 \\
\hline$P_{\mathrm{M}}-E_{\mathrm{M}}$ & $-22(50)$ & $-18(186)$ & $-15(13)$ \\
\hline$P_{\mathrm{M}}-E_{\mathrm{M}}+R_{\mathrm{M}}$ & -36 & -33 & -41 \\
\hline
\end{tabular}

$\mathrm{HM}=$ differences between the HiRes and MedRes model means are not statistically significant at the 5\% significance level. $\mathrm{HL}=$ differences between the HiRes and LoRes model means are not statistically significant at the 5\% significance level. ML $=$ differences between the MedRes and LoRes model means are not statistically significant at the $5 \%$ significance level. ***Denotes where there is no runoff in the model

Table 11 Future model runoff ratio values (runoff/precipitation) for the Mediterranean Sea sub-basins

\begin{tabular}{llll}
\hline & \multicolumn{2}{l}{ Runoff/precipitation } \\
\cline { 2 - 4 } & HiRes & MedRes & LoRes \\
\hline Alboran & 0.05 & 0.02 & 0.00 \\
South-Western & 0.01 & 0.00 & 0.00 \\
North-Western & 0.26 & 0.20 & 0.18 \\
Tyrrhenian & 0.11 & 0.05 & 0.00 \\
Adriatic & 0.36 & 0.29 & 0.30 \\
Ionian & 0.12 & 0.04 & 0.03 \\
Central & 0.00 & 0.00 & 0.00 \\
Aegean & 0.15 & 0.12 & 0.09 \\
North-Levantine & 0.16 & 0.08 & 0.07 \\
Black Sea & 0.21 & 0.21 & 0.19 \\
\hline
\end{tabular}

Table 12 Percent change in average runoff values (coefficient of variation) in the Caspian Sea basin

\begin{tabular}{llll}
\hline & HiRes & MedRes & LoRes \\
\hline Volga & $-3(3)$ & $5(3)$ & $-9(52)$ \\
Kura & $-5(84)$ & $4(5)$ & $0(56)$ \\
Ural & $38(-16)$ & $20(-38)$ & $* * *$ \\
$R_{\mathrm{C}}$ & -2 & 6 & -6 \\
$P_{\mathrm{C}}-E_{\mathrm{C}}$ & $-7(-20)$ & $-6(-18)$ & $4(-13)$ \\
$P_{\mathrm{C}}-E_{\mathrm{C}}+R_{\mathrm{C}}$ & -60 & -6 & -28 \\
\hline
\end{tabular}

$\mathrm{HM}=$ differences between the HiRes and MedRes model means are not statistically significant at the 5\% significance level. HL $=$ differences between the HiRes and LoRes model means are not statistically significant at the 5\% significance level. $\mathrm{ML}=$ differences between the MedRes and LoRes model means are not statistically significant at the $5 \%$ significance level

Table 13 Future model runoff ratio values (runoff/precipitation) for the Caspian Sea basins

\begin{tabular}{llll}
\hline & \multicolumn{2}{l}{ Runoff/precipitation } \\
\cline { 2 - 4 } & HiRes & MedRes & LoRes \\
\hline Volga & 0.21 & 0.16 & 0.12 \\
Kura & 0.22 & 0.25 & 0.34 \\
Ural & 0.06 & 0.02 & 0.00 \\
\hline
\end{tabular}

In this study we have given an evaluation of how well the ARPEGE-CLIMATE V4 global model is able to reproduce the hydrological balance of the Mediterranean, Black and Caspian Sea basins. We have also shown that the model's performance improves significantly with increased resolution, especially in regions with mountainous terrain. Although resolution does not seem to have a significant effect on the qualitative impacts of future climate change on the hydrologic balance, quantitatively the results vary significantly among the models. The HiRes model simulates a lower decrease in river runoff and a larger decrease in $P-E$ over the sea. These results suggests that high resolution global models, or downscaling models such as RCMs, are necessary in order to assess the magnitude of future changes in the hydrological components of these basins.

It is worth noting that the models used in this study were not coupled to an ocean model. Furthermore, the SST anamolies used for the future climate scenario were extracted from a previously run low-resolution AOGCM. Therefore, the high-resolution ocean feedback which can have a regional impact on precipitation in climate change scenarios (Somot et al. 2008) and consequently on the change in water budget are not taken into account. Global or regional high-resolution coupled climate models would be the ideal modelling tool when assessing the change in 
the water budget of regional seas as the Mediterranean, Black and Caspian seas.

Acknowledgments The authors would like to thank the anonymous reviewers for their suggestions which greatly helped to improve this paper.

\section{References}

Alpert P, Ben-Gai T, Baharad A, Benjamini Y, Yekutieli D, Colacino M, Diodato L, Ramis C, Homar V, Romero R, Michaelides S, Manes A (2002) The parodoxical increase of Mediterranean extreme daily rainfall in spite of decrease in total values. Geophys Res Lett 29(11). doi:10.1029/2001GL013554

Arpe K, Leroy S (2007) The Caspian sea level forced by the atmospheric circulation, as observed and modelled. Q Int 173 174:144-152. doi:10.1016/j.quaint.2007.03.008

Baschek B, Send U, Lafuente J, Candela J (2001) Transport estimates in the strait of Gibraltar with a tidal inverse model. J Geophys Res 106:31033-31044

Bethoux (1993) Mediterranean sapropel formation, dynamic and climatic viewpoints. Atmos Ocean 16:127-133

Bethoux J (1979) Budgets of the mediterranean sea. Their dependence on the local climate and on the characteristics of the atlantic waters. Oceanol Acta 2:157-163

Bethoux J, Gentili B (1999) Functioning of the Mediterranean sea: past and present changes related to freshwater input and climate changes. J Mar Syst 20:33-47

Bougeault P (1985) A simple parameterization of the large-scale effects of cumulus convection. Mon Weather Rev 113:21082121

Boukthir M, Barnier B (2000) Seasonal and interannual variations in the surface freshwater flux in the Mediterranean sea from the ecmwf re-analysis project. J Mar Syst 24:343-354

Bryden H, Candela J, Kinder T (1994) Exchange through the strait of Gibralter. Oceanography 33:201-248

Candela J (2001) The Mediterranean water and the global circulation. In: Observing and modelling the Global Ocean. Academic Press, San Diego

Castellari S, Pinardi N, Leaman K (1998) A model study of air-sea interactions in the Mediterranean sea. J Mar Syst 18:89-114

Cruzado A (1985) Chemistry of Mediterranean waters. In: Margalef R (ed) Western Mediterranean. Pargamon Press, Oxford, pp 126-147

Déqué M, Dreveton C, Braun A, Cariolle D (1994) The arpege-ifs atmosphere model: a contribution to the french community climate modelling. Clim Dyn 10:249-266

Douville H, Planton S, Royer J, Stephenson D, Tyteca S, Kergoat L, Lafont S, Betts R (2000) The importance of vegetation feedbacks in doubled- $\mathrm{CO}_{2}$ time-slice experiments. $\mathrm{J}$ Geophys Res 105:14841-14861

Elguindi N, Giorgi F (2005) Simulating multi-decadal variability of Caspian sea level changes using regional climate model outputs. Clim Dyn 26:167-181

Elguindi N, Giorgi F (2007) Simulating future Caspian sea level changes using regional climate model outputs. Clim Dyn 28:365-379

French Ministry of Environment (2006) Hydro. Data were downloaded at: http://hydro.rnde.tm.fraccueil.htm

Garcia-Lafuente J, Sanchez-Roman GSA, Diaz-Delrio G, SanchezGarrido J (2007) Recent observations of seasonal variability of the Mediterranean outflow in the strait of Gibraltar. J Geophys Res 112:1-11

Georgievsky V, Tsytsenko K, Shalygin A (2003) Assessment of surface water inflow to the Caspian Sea-Hydrometeorological issues of problem of the Caspian sea and its basin-Spb. Hydrometeoizdat 217-229 (in Russian)

Gibelin A-L, Déqué M (2003) Anthropogenic climate change over the mediterranean region simulated by a global variable resolution model. Clim Dyn 20:327-339

Giorgi F (2006) Climate change hot-spots. Geophys Res Lett 33(8). doi:10.1029/2006GL025734

Giorgi F, Bi X, Pal J (2004) Mean, interannual variability and trends in a regional climate change experiment over Europe. i. presentday climate (1961-1990). Clim Dyn 22:733-756

Holdridge L (1959) Simple method for determining potential evapotranspiration from temperature data. Science 130(3375):572

Jacob D, Brring L, Christensen OB, Christensen JH, de Castro M, Dqu M, Giorgi F, Hagemann S, Hirschi M, Jones R, Kjellstrm E, Lenderink G, Rockel B, Snchez E, Schr C, Seneviratne SI, Somot S, van Ulden A, van den Hurk B (2007) An intercomparison of regional climate models for Europe: model performance in present-day climate. Clim Change 81:31-52

Josey S (2003) Changes in the heat and freshwater forcing of the eastern Mediterreanean and their influence on deep water formation. J Geophys Res 108:1-18. doi:10.1029/2003JC001778

Kara A, Wallcraft A, Hurlburt H, Stanev E (2008) Air-sea fluxes and river discharges in the Black sea with a focus on the danube and bosphorus. J Mar Syst. doi:10.1016/j.jmarsys.2007.11.010

Lacombe H, Tchernia P (1972) Caracteres hydrologiques et circulation des eaux en Mediterranee. The Mediterranean Sea: a Natural Sedimentation Laboratory. D.J. Stanley

Lott F (1999) Alleviation of stationary biases in a $\mathrm{gcm}$ through a mountain drag parameterization scheme and a simple representation of mountain lift forces. Mon Weather Rev 125:788-801

Lott F, Miller M (1997) A new subgrid-scale orographic drag parametrization: its formulation and testing. Q J R Meteorol Soc 123:101-127

Ludwig W, Dumont E, Meybeck M, Heusser S (2009) River discharge of water and nutrients to the Mediterranean and Black sea: major drivers for ecosystem changes during past and future decades? Prog Oceanogr 80:199-217

Malanotte-Rizzoli P, Manca B, d'Alcal MR, Theocharis A, Brenner GBS, Ozsoy E (1999) The eastern Mediterranean in the 80's and in the 90's: the big transition in the intermediate and deep circulations. Dyn Atmos Oceans 29:365-395

Mariotti A, Struglia M (2002) The hydrological cycle in the Mediterranean region and implications for the water budget of the Mediterranean sea. J Clim 15:1674-1690

Mariotti A, Zeng N, Yoon J, Artale V, Navarra A, Alpert P, Li L (2008) Mediterranean water cycle changes: transition to drier 21 st century conditions in observations and cmip3 simulations. Environ Res Lett 3. doi:10.1088/1748-9326/3/4/044001

Medhycos (2001) The Mediterranean hydrological cycle observing system. Medhycos phase ii, period 2002-2005. http://medhycos. mpl.ird.fr

Millot C, Candela J-L, Tber Y (2006) Large warming and salinification of the Mediterranean outflow due to changes in its composition. Deep Sea Res 53:656-666

Morcrette J (1990) Impact of changes to the radiation transfer parameterizations plus cloud optical properties in the ecmwf model. Mon Weather Rev 118:847-873

Myers P, Haines K, Josey S (1998) On the importance of the choice of wind stress forcing to the modeling of the Mediterranean sea circulation. J Geophys Res 103, 15,729-15,749

New M, Lister D, Hulme M, Makin I (2002) A high-resolution data set of surface climate over global land areas. Clim Res 21:1-25

Nixon S (2003) Replacing the nile: are anthropogenic nutrients providing the fertility once brought to the mediterranean by a great river? Ambio 32:30-39 
Pike J (1964) The estimation of annual runoff from meteorological data in a tropical climate. J Hydrol 2:116-123

Potter R, Lozier S (2004) On the warming and salinification of the Mediterranean outflow waters in the north Atlantic. Geophys Res Lett 31:101202. doi:10.1029/2003GL018161

Poulos M, Drakpooulos P (2001) A reassessment of the Mediterranean river runoff. Rapp Comm Int Mer Med 36:76

Ricard J, Royer J (1993) A statistical cloud scheme for use in an agcm. Ann Geophys 11:1095-1115

Rodionov S (1994) Global and regional climate interaction: the Caspian Sea experience. Kluwer, Dordrecht

Roether W, Klein B, Manca BB, Theocharis A, Kioroglou S (2007) Transient eastern Mediterranean deep waters in response to the massive dense-water output of the Aegean sea in the 1990s. Prog Oceanogr 74:540-571

Rohling E, Bryden H (1992) Man-induced salinity and temperature increases in western mediterranean deep water. J Geophys Res 97:11919-11198

Sanchez-Gomez E, Somot S, Josey SA, Elguindi N, Déqué M (2009a) Evaluation of the Mediterranean sea water and heat budgets as simulated by an ensemble of high resolution regional climate models. J Geophys Res Oceans (submitted)

Sanchez-Gomez E, Somot S, Mariotti A (2009b) Future changes in the Mediterranean water budget projected by an ensemble of regional climate models. Geophys Res Lett 36. doi:10.1029/ 2009GL040120

Schroeder K, Ribotti A, Borghini M, Sorgente R, Perilli A, Gasparini GP (2008) An extensive western Mediterranean deep water renewal between 2004 and 2006. Geophys Res Lett 35. doi: 10.1029/2008GL035146

Sheffield J, Wood E (2008) Projected changes in drought occurence under future global warming from multi-model, multi-scenario scenario, ipcc ar4 simulations. Clim Dyn 31:79-105

Shiklomanov I, Georgievsky V, Shalygin A (2003) Reasons of the caspian sea level rise-hydrometeorological issues of problems of the Caspian sea and its basin-Spb. Hydrometeoizdat 254 266 (in Russian)

Skliris N, Lascaratos A (2004) Impacts of the Nile river damming on the thermohaline circulation and water mass characteristics of the Mediterranean sea. J Meteorol Soc 52:121-143

Somot S, Sevault F, Déqué M (2006) Transient climate change scenario simulation of the Mediterranean sea for the twenty-first century using a high-resolution ocean circulation model. Clim Dyn 27:851-879
Stanev E, Traon P-YL, Peneva E (2000) Sea level variations and their dependency on meteorological and hydrological forcing: analysis of altimeter and surface data for the black sea. J Geophys Res 105:17203-17216

Struglia M, Mariotti A, Filograsso A (2004) River discharge into the Mediterranean sea: climatology and aspects of the observed variability. J Clim 17:4740-4751

Thorpe R, Bigg G (2000) Modelling the sensitivity of the Mediterranean outflow to anthropogenically forced climate change. Clim Dyn 16:355-368

Tixeront J (1970) Le bilan hydrologique de la mer noire et de la mer méditerranéé. Cah Oceanogr 3:227-236

Tomczak M, Godfrey J (1994) Regional oceanography: an introduction. Pargamon, Great Britain, pp 300-309

Trigo I, Davies T, Bigg G (2000) Decline in Mediterranean rainfall caused by weakening of Mediterranean cyclones. Geophys Res Lett 27(18). doi:10.1029/2000GL011526

Tsimplis M, Baker T (2000) Sea level drop in the Mediterranean sea: an indicator of deep-water salinity and temperature changes? Geophys Res Lett 27:1731-1734

Uppala S, Kallberg P, Simmons A, Andrae U, Bechtold VDC, Fiorino M, Gibson J, Haseler J, Hernandez A, Kelly G, Li X, Onogi K, Saarinen S, Sokka N, Allan R, Adersson E, Arpe K, Balmaseda M, Beljaars A, Berg LVD, Bidlot J, Bormann N, Caires S, Chevallier F, Dethof A, Dragosavac M, Fisher M, Fuentes M, Hagemann S, Holm E, Hoskins B, Isaksen L, Janssen P, Jenne R, McNally A, Mahfouf J-F, Morcrette J-J, Rayner N, Saunders R, Simon P, Sterl A, Trenberth K, Untch A, Vasiljevic D, Viterbo P, Woollen J (2005) The era-40 reanalysis. Q J R Meteorol Soc $131,2961-3012$

Valero F, Doblas F, Gonzales J (1996) On long-term evolution of seasonal precipitation in southwestern europe. Ann Geophys 14:976-985

Vorosmarty C, Fekete B, Tucker B (1998) River discharge database, version1.1 (rivdis v1.0 supplement). Available through the institute for the study of earth, oceans, and space/university of new hampshire, durham nh (USA)

Xoplaki E, Luterbacher J, Burkard R, Patrikas I, Maheras P (2000) Connection between the large-scale 500 hpa geopotentiel height fields and precipitation over greece during wintertime. Clim Res $14,129-146$

Zervakis V, Georgopoulos D, Drakopoulos P (2000) The role of the North Aegean in triggering the recent eastern Mediterranean climatic changes. J Geophys Res 105:26103-26116 